\title{
Antitrust and the Market for Corporate Control
}

\author{
Edward B. Rock \\ TABLE of Contents
}

Introduction ................................... 1367

I. The Importance of Competition in the Market for

Corporate Control ............................. 1370

A. The Antitrust Perspective $\ldots \ldots \ldots \ldots \ldots \ldots \ldots \ldots \ldots \ldots \ldots \ldots \ldots 1371$

1. Distributional Effects ..................... 1372

2. Allocational Effects ..................... 1376

a. Allocating Control to the Highest

Valuing User ........................ 1376

i. Effects of Bidding Agreements on

Potential Bidders .................... 1377

ii. Efficient Allocation Among Bidders ....... 1377

b. Potential Allocational Inefficiencies from the

Distributional Effects ................... 1381

B. The Importance of Protecting Competition

for Control, Regardless of One's Views

Concerning Takeovers

II. The Arguments Against Protecting Competition for

Corporate Control ............................. 1386

A. The Principal Case: Kalmanovitz v. Heileman ........ 1387

1. A Critique............................ 1388

B. Preeinption/Implied Immunity Under the

Williams Act.............................. 1391

1. The Williams Act and the Shernan Act Do Not Impose Inconsistent Requirements on Bidders .... 1391

2. Legislative History of the Williams Act.......... 1393

3. Judicial Interpretation of the Scope of the Williams Act ............................. 1394

C. The SEC and Bidding Agreements ................ 1396

D. The Fit with Delaware Law .................... 1399

E. The First Conclusion: Antitrust Slould Apply ....... 1401

III. Towards an Antitrust Jurisprudence of the Market for

Corporate Control ............................... 1402

A. The Problem: The Variety of Agreements .......... 1402 
B. Preliminary Considerations .................... 1403

C. Joint Ventures in the Market for Corporate Control: Sorting Out the Hard Cases ...................... 1405

1. The Scope of the Per Se Rule ................ 1406

a. Naked Bidding Agreements Among

Competitors Are Per Se Illegal............... 1407

b. The Same Rule for the Market for Control ..... 1408

c. The Boundaries of the Per Se Rule............ 1410

2. Limiting Principles Within the Rule of Reason .... 1412

a. Substance Over Form................... 1412

b. The First Principle: Actual or Potential

Competitors......................... 1412

c. The Second Principle: Power Over Price ...... 1413

3. The Hard Cases ............................. 1414

D. Subsidiary Questions ........................ 1417

1. Who Is a Bidder? ........................ 1417

2. Market Power ........................ 1418

E. Greenmail Through the Antitrust Lens............ 1421

Conclusion .................................... 1427 


\title{
Antitrust and the Market for Corporate Control
}

\author{
Edward B. Rock $\dagger$
}

Competition for corporate control is important both because of its economic effects and because of the part it plays in corporate governance. In this Article, Professor Rock examines the role of the antitrust laws in protecting the basic competitive processes within the market for corporate control. $\mathrm{He}$ argues, contrary to the few cases on point, that the antitrust laws should protect competition in the market for control, just as they protect competition in other markets. He then provides a general framework for applying antitrust to the market for control and applies that framework to bidding agreements in tender offer auctions, concluding that naked restraints of trade in the market for control should be considered per se violations of the antitrust laws.

\section{INTRODUCTION}

In this Article, I examine the appropriate role of the antitrust laws in the market for corporate control. ${ }^{1} \mathrm{I}$ argue that the protections that antitrust law provides to basic competitive processes in other markets

$\dagger$ Assistant Professor of Law, University of Pennsylvania Law School. B.S. 1977, Yale University; B.A. 1980, Oxford University; J.D. 1983, University of Pennsylvania. I am grateful to Allen Black, Aaron Fine, Frank Goodman, Arthur Kaplan, Seth Kreimer, Friedrich Kübler, Peter Linneman, Robert Mundheim, Donald Perelman, Almarin Phillips, Michael Schill, Michael Wachter, and Elizabeth Warren for commenting on earlier drafts, and to the participants of the University of Pennsylvania Law School's ad hoc seminar for helpful comments on a half-baked version. Financial support for this research was provided by the University of Pennsylvania Law School's Institute for Law and Economics.

1. This Article is part of a larger project examining the appropriate role for antitrust principles and protections in corporate law. Over the last 15 years, corresponding to increases in the prominence of the hostile takeover, the competitiveness of the market for corporate control, and the influence of the law and economics approach, many scholars have come to agree that competition for control plays an important role in corporate law. In this project, I take that insight seriously, examining corporate law from the perspective of the laws protecting competition.

This Article deals with the fundamental preliminary question whether the antitrust laws do and should apply to inter-corporate arrangements in the inarket for corporate control, and, if so, how. In subsequent articles, I will examine the relationship between federal competition law and state corporate law, focusing on the effect, if any, of the antitrust laws on the validity of state attempts to shield loeal corporations from competition for control. I will also examine the role, if any, for antitrust principles in the intra-corporate sphere, with emphasis on the applicability of antitrust principles to competition among shareholders to tender. The second stage of the project can be framed as follows: Once one breaks down the conceptual distinction between the firm and the market, by conceptualizing the firm as a network of contracts, what protections of the market, broadly construed, are appropriate? 
should extend to the market for control. ${ }^{2}$

The increasing popularity and importance of competitive auctions for control makes the proper role of antitrust in the market for corporate control an issue of more than just academic interest. ${ }^{3}$ In some cases, agreements among competing bidders have ended these auctions. For example, the recent battle for control of J.P. Stevens resulted in vigorous escalating bidding between Odyssey Partners, a New York investment partnership, and West Point-Pepperell, a major textile manufacturer. The contest ended abruptly when Odyssey and West Point agreed to stop bidding against each other, to join forces, and to divide the assets of Stevens. ${ }^{4}$ The 1988 battle for control of Federated Department Stores followed a similar pattern. There Campeau Corporation and R.H. Macy Company ended the bidding contest by private agreement, both bidders having concluded that a "bidding frenzy" had begun to build. ${ }^{5}$ In sev-

2. The seminal work on the connection between antitrust and the market for corporate control is, of course, Manne, Mergers and the Market for Corporate Control, 73 J. Pol. Econ. 110 (1965). My debt to Professor Manne's insights will be clear in much of what follows. Our perspectives differ somewhat. Professor Manne argued that the aggressive enforcement of section 7 of the Clayton Act was inappropriate because, by limiting the firms that could merge, it undermined the competitiveness of the market for control, thereby limiting market discipline on management. My argument is somewhat complementary. I agree with Professor Manne on the importance of competition for control and argue for the apphication to the market for corporate control of those provisions of the antitrust laws that protect the competitive process, principally section 1 of the Sherman Act.

3. See Landefeld, Business Auctions Take Hold, Nat'1 L.J., May 15, 1989, at S2-3.

4. With Odyssey's bid at $\$ 68.50$ and West Point's bid at $\$ 67$, the Federal Trade Commission gave preliminary antitrust clearance to West Point's bid, subject to the previously arranged sale of a number of Stevens' divisions to NTC Group, Inc. (another textile manufacturer), a development that was expected to spark substantially higher offers. N.Y. Times, Apr. 26, 1988, at D1, col. 3. At that point, NTC's chairman approached an investor in Odyssey Partners and proposed that the competing bidders join forces and divide the assets of Stevens. Id. Shortly thereafter, the West Point group and Odyssey Partners entered into a written agreement under which the parties explicitly agreed that Odyssey would stop bidding against West Point, that West Point would acquire the sliares of Stevens for $\$ 68.50$ per share, and that West Point, NTC, and Odyssey would divide up the assets of Stevens among themselves. Id.; see also Schedule 14D-1, JPS Acquisition Corp. (Amendment No. 9), item 3 \& exhibits (a)(30)-(33) (tender offer statement filed with the SEC by a wholly-owned subsidiary of JPS Holding Corporation, an affiliate of Odyssey Partners). The West Point group then acquired $85 \%$ of Stevens by its tender offer, Wall St. J., May 10, 1988, at 51, col. 1, and the remainder in a subsequent merger. N.Y. Times, July 1, 1988, at D4, col. 3. As a result of the bidding agreement, West Point, NTC, and Odyssey split the assets of Stevens. N.Y Times, Aug. 4, 1988, at D4, col. 5.

5. The circumstances of this particular agreement reveal a great deal about why bidders enter into such agreements. Campeau and Macy's submitted numerous escalating bids for Federated. Federated's board then set the guidelines for a "final" round of bidding. N.Y. Times, Mar. 29, 1988, at D1, col. 6. On March 30, 1988, Campeau and Macy's submitted their "final" bids. N.Y. Times, Mar. 31, 1988, at D1, col. 3. Macy's submitted a bid valued at $\$ 73.88$ per share, and Campeau bid $\$ 74$ per share. N.Y. Times, Apr. 1, 1988, at D3, col. 4. That evening, Federated told Macy's that Campeau had submitted the higher bid. Id. Mistakenly thinking that Campeau had offered the equivalent of \$75.50, Macy's decided to bid \$75.14 and the regular quarterly dividend of \$0.37, for a total value of $\$ 75.51$ per share. Id.

On the morning of March 31, Macy's made its revised bid. Id. During that day, Federated's 
eral other high profile battles for control, one bidder has dropped out in return for a direct payment from the remaining bidder. ${ }^{6}$

Such agreements squarely raise the question of antitrust's role in the market for corporate control. In other markets, agreements among competing bidders not to bid are per se violations of the antitrust laws. ${ }^{7}$ Thus, the question arises whether such agreements in the market for corporate control are or should be illegal.

One's perception of the plausibility of applying antitrust to the market for control may vary with one's sense of the world. From the antitrust perspective, there is a very strong presumption that antitrust apphies to all markets. Likewise, if one views corporate law as relying significantly on competition for control, the notion that competition should be protected by invoking our fundamental competition law, rather than by more or less ad hoc extensions of traditional corporate or securities law, also seems intrinsically plausible. But to those for whom hostile takeovers are something of a fad and not a fundamental feature of corporate regulation, the prospect of applying the antitrust laws to the market for control may seem unnecessary. To others, the idea of applying basic antitrust principles to the market for corporate control may simply be novel enough to make it seem odd and inappropriate. Alternatively, traditional corporate law scholars' loyalty to their field may lead them to resist the incursion of a foreign, unfamiliar field.

board accepted neither bid, saying that it would keep the auction open while it evaluated Macy's late offer and gave Campeau a chance to submit an additional bid. N.Y. Times, Apr. 2, 1988, at 33, col. 1. By early in the afternoon, both Macy's and Campeau had concluded that the auction process had "broken down" and, to the detriment of both bidders, a "bidding frenzy" had begun to build. Id. By 10:00 p.m., Campeau and Macy's had reached an agreement to end the bidding auction. Id. Macy's agreed to drop its bid in return for the right to purchase two Federated divisions. Id. In addition, Campeau agreed to pay Macy's legal and investment banking fees, estimated to exceed $\$ 60$ million. Id. Subsequently, Campeau and Federated agreed that Campeau would acquire Federated for \$73.50 per share in cash, and that Macy's would buy two Federated divisions. Id. at 33, col. 5 . The difference between Campeau's final price of $\$ 73.50$ per share and Macy's high bid of $\$ 75.51$ was just over $\$ 2$ per share, or about $\$ 172$ million. (Approximately 86 million shares were then outstanding.) This figure does not include any additional amounts that Campeau or Macy's might have bid had the auction continued. A Federated shareholder unsuccessfully challenged the Campeau-Macy's bidding agreeınent in Finnegan v. Campeau Corp., 1989-2 Trade Cas. (CCH) II 68,816 (S.D.N.Y. 1989), appeal docketed, No. 89-9183 (2d Cir. Nov. 27, 1989).

6. For example, in Asher Edelman's battle to acquire control of Fruehauf Corporation, the bidding war between Edelman and a management buyout group ended when the management group agreed to buy Edelman's 2 million shares for cash (as compared to the package of cash and securities offered other shareholders) plus a payment of $\$ 21$ million "for expenses." N.Y. Times, Aug. 23, 1986, at 29, col. 4. In the 1988 battle for control of American Standard, Incorporated, Black \& Decker dropped its bid in return for a $\$ 25$ million payment from Kelso \& Company, the competing bidder. N.Y. Times, Mar. 23, 1988, at D1, col. 6; Wall St. J., Mar. 23, 1988, at A5, col. 1. (Kelso had earlier indicated that it might incrcase its offer, N.Y. Times, Mar. 22, 1988, at D5, col. 2; Wall St. J., Mar. 21, 1988, at A6, col. 2, but, as the New York Times pointed out, the $\$ 25$ million payment was less costly to Kelso than another round of bidding. N.Y. Times, Mar. 23, 1988, at D21, col. 5.)

7. See infra text accompanying notes $180-83$. 
One of the purposes of this Article is to show that, whatever one's view of the world, antitrust should be applied to the market for corporate control. I also respond to a concern that may underlie some resistancea sense that antitrust is an overly cumbersome set of regulations that should not be extended beyond its traditional domain. It is my view that protecting competition is antitrust's traditional domain, and that one can apply basic protections against restraints of competition in the market for control in a sensible and administrable fashion.

In Part I, I examine the importance of competition in the market for control and show that bidding agreements threaten fundamental goals of both antitrust and corporate law. I consider the principal arguments against the application of antitrust to the market for control in Part II. I show that neither the linguistic argument in the principal case, Kalmanovitz v. G. Heileman Brewing Co., ${ }^{8}$ nor any preemption or imphed immunity argument supports exempting the market for control from antitrust protections and that application of the antitrust laws would reinforce the underlying purposes and assumptions of the federal regulation of tender offers, as well as the assumptions of state regulation. In Part III, having concluded that the antitrust laws should apply to the market for control, I sketch out a general analysis of how they should be implemented. I then apply my general analysis to targeted share repurchases, better known as "greenmail."

I

\section{THE IMPORTANCE OF COMPETITION IN THE MARKET FOR CORPORATE CONTROL}

The "market for control" is a market in which the commodity traded is corporate control. ${ }^{9}$ It looks like a market, it acts like a market, and it is viewed as a market by its participants. ${ }^{10}$ Antitrust is a law of general application, protecting basic competitive processes in all markets. Accordingly, there is a very strong, prima facie case for applying antitrust to the market for control. ${ }^{11}$

8. 769 F.2d 152 (3d Cir. 1985).

9. See CTS Corp. v. Dynamics Corp. of Am., 481 U.S. 69, 94 (1987) ("[T]he very commodity that is traded in the 'market for corporate control' [is] the eorporation . . . .").

10. Individual "raiders" and acquisition-minded corporations are regular players in the market for control. Investment bankers, lawyers, and a small group of commercial banks act as intermediaries or provide other specialized services. Many investment banking and law firms now have separate "M\&A" departments or groups. Law schools and business schools offer courses in mergers and acquisitions. There are even publications devoted to reporting on the activities within the market for control. For an example of the latter, see any issue of MERGERS \& ACQU1S1T1ONS.

11. See, e.g., FTC v. Superior Court Trial Lawyers Ass'n, 110 S. Ct. 768 (1990) (rejecting argument that antitrust should not apply to unusual market for representation of indigent criminal defendants); Arizona v. Maricopa County Medical Soc'y, 457 U.S. 332 (1982) (rejeeting argument that antitrust should not apply to the medical profession); National Soc'y of Professional Eng'rs v. 
The issue of whether antitrust should apply to the market for control must be separated from the issue of how it should apply. The first issue is whether the basic competitive processes in the market for control should be subject to the reach of the antitrust laws. There are two substantive reasons for protecting competition in the market for control. From the antitrust perspective, competition in the market for control, like competition in other markets, serves important economic, social, and political purposes. From the perspective of corporate governance, competition in the market for control plays an important role in controlling the potential conflict of interest between shareholders and managers. ${ }^{12}$ The subject of this Part is the need for antitrust protections in the market for corporate control. The issue of how antitrust should apply is the focus of Part III, where I sketch out a general antitrust jurisprudence for the market for corporate control.

\section{A. The Antitrust Perspective}

The same factors that lead us to prohibit agreements displacing

United States, 435 U.S. 679, $689-90$ (1978) (antitrust applicable to the engineering profession); Goldfarb v. Virginia State Bar, 421 U.S. 773 (1975) (rejecting argument that antitrust should not apply to the legal profession); United States v. Joint Traffic Ass'n, 171 U.S. 505, 575-77 (1898) (railroad rate-setting agencies subject to antitrust laws); United States v. Trans-Missouri Freight Ass'n, 166 U.S. 290 (1897) (same).

12. The competition perspective differs significantly from the corporate governance perspective. This difference may partially explain the gulf between the opinions of the Delaware courts and the writings of scholars concerned with competition in the market for control. The Delaware judges are concerued primarily with corporate governance, whereas the market for control scholars are mostly concerned with how competition in the market for control can be maximized or optimized.

The differences in the respective analyses of defensive strategies is illustrative. The Delaware courts ask whether the actions of the directors are appropriate in light of their duties to the shareholders and the powers conferred on the board under the Delaware corporation law. See, e.g., Unocal Corp. v. Mesa Petroleum Co., 493 A.2d 946 (Del. 1985) (court will not substitute its judgment for that of the board of directors so long as the board's response is reasonably proportional to a perceived threat to the corporation or its shareholders). The market for control scholars ask whether defensive strategies interfere with or facilitate competition in the market for control. See Bebchuk, The Case for Facilitating Competing Tender Offers, 95 HARv. L. REv. 1028, 1054-56 (1982) [hereinafter Bebchuk, Facilitating Competing Tender Offers]; Bebchuk, The Case for Facilitating Competing Tender Offers: A Reply and Extension, 35 STAN. L. REv. 23, 47 (1982) [hereinafter Bebchuk, Reply and Extension]; Easterbrook \& Fischel, Auctions and Sunk Costs in Tender Offers, 35 STAN. L. REv. 1, 1-3 (1982) [hereinafter Easterbrook \& Fischel, Auctions and Sunk Costs]; Easterbrook \& Fischel, The Proper Role of a Target's Management in Responding to a Tender Offer, 94 HARV. L. REv. 1161, 1174-82 (1981) [hereinafter Easterbrook \& Fischel, Proper Role]; Gilson, A Structural Approach to Corporations: The Case Against Defensive Tactics in Tender Offers, 33 STAN. L. REV. 819, 868-75 (1981) [hereinafter Gilson, Structural Approach]; Gilson, Seeking Competitive Bids Versus Pure Passivity in Tender Offer Defense, 35 STaN. L. REv. 51, 52, 56 (1982) [hereinafter Gilson, Seeking Competitive Bids]. Indeed, it is somewhat surprising that the two approaches ever lead to the same conclusion. They tend to converge because, under Delaware law, directors manage the corporation for the shareholders, and shareholders generally benefit from competition in the market for control. 
competition in other markets-the wealth transfers (distributional effects) and inefficiencies (allocational effects) - should lead us to protect competition in the market for control. In this Article, I assume that both the distributional ${ }^{13}$ and allocational ${ }^{14}$ effects of agreements displacing competition are of direct concern to antitrust.

\section{Distributional Effects}

One of the most dramatic and, from the point of view of the target company's shareholders, most welcome developments during a tender offer is the appearance of a competing bidder. As in any auction, competing bidders drive prices up. A recent study indicates that target shareholders receive a premium of $42-46 \%$ in multiple-bidder tender offers,

13. Under traditional antitrust analysis, the redistribution of wealth resulting from agreements that displace competition is of central concern. See, e.g., Fox, The Modernization of Antitrust: A New Equilibrium, 66 CORNELl L. REv. 1140, 1147, 1166, 1182-90 (1981); Fox \& Sullivan, Antitrust: Retrospective and Prospective: Where Are We Coming From? Where Are We Going?, 62 N.Y.U. L. REv. 936, 970-71, 982 (1987); Harris \& Jorde, Antitrust Market Definition: An Integrated Approach, 72 CALIF. L. REV. 1, 14-18 (1984); Kaplow, The Accuracy of Traditional Market Power Analysis and a Direct Adjustment Alternative, 95 HARV. L. REv. 1817, 1822 (1982); Lande, Wealth Transfers as the Original and Primary Concern of Antitrust: The Efficiency Interpretation Challenged, 34 HASTINGS L.J. 65, 74-76, 93-96 (1982) (citing and quoting legislative history); Sullivan, The Viability of the Current Law on Horizontal Restraints, 75 CAL1F. L. REv. 835, 852-53, 852 n.76 (1987); Scherer, The Posnerian Harvest: Separating Wheat from Chaff (Book Review), 86 YAl. L.J. 974, 977-78 (1977) (reviewing R. POSNER, ANTITRUST LAw: AN ECONOM1C PERSPECT1VE (1976)).

These distributional effects matter, in large measure, for reasons of fairness, regardless of whether the underlying transaction is also allocationally inefficient. See, e.g., Klor's, Inc. v. Broadway-Hale Stores, Inc., 359 U.S. 207, 213 (1959). The notion of fairness embodied in the antitrust laws is a belief that all market participants, regardless of size or economic power, are entitled to free and open markets, unfettered by clogs on competition, especially those created by private agreements whose purpose is to displace competition. This concept reflects a deeply rooted, widely held intuition that when one is buying or selling, one has a right to the benefits provided by competition. Thus a seller deservedly feels cheated when receiving a lower price because bidders have undermined the competitive process by private agreements. See, e.g., Reiter v. Sonotone Corp., 442 U.S. 330, 342 (1979) ("The essence of the antitrust laws is to ensure fair price competition in an open market."); United States v. Topco Assocs., Inc., 405 U.S. 596, 610 (1972) (“Antitrust laws in general, and the Sherman Act in particular, are the Magna Carta of free enterprise. They are as important to the preservation of economic freedom and our free enterprise system as the Bill of Rights is to the protection of our fundamental personal freedoms."); Klor's, Inc., 359 U.S. at 213 ("This combination [of manufacturers, distributors, and a retailer] takes from [plaintiff] its freedom to buy appliances in an open competitive market and drives it out of business as a dealer in the defendants' products. . . . As such it is not to be tolerated merely because the victim is just one merchant whose business is so small that his destruction makes little difference to the economy."); Northern Pac. Ry. v. United States, 356 U.S. 1, 4 (1958) ("The Sherman Act was designed to be a comprehensive charter of economic liberty aimed at preserving free and unfettered competition as the rule of trade."); Fashion Originators' Guild, Inc. v. FTC, 312 U.S. 457, 465 (1941); United States v. Socony-Vacuum Oil Co., 310 U.S. 150, 223 (1940); see also Schwartz, "Justice" and Other NonEconomic Goals of Antitrust, 127 U. PA. L. REV. 1076 (1979).

14. Decreases in allocational efficiency matter because they make society worse off than it need be. See generally R. Bork, The ANTITRust PARAdox (1978); R. POSNER, ANTitrust LAW: AN ECONOMIC PERSPECTIVE (1976). 
compared to a premium of $26-30 \%$ in single-bidder offers. ${ }^{15}$ Froin an ex post perspective, ${ }^{16}$ an agreement among bidders competing for control, like a bidding agreeinent in any other market, transfers wealth froin target shareholders to acquirers. ${ }^{17}$ The seller loses a benefit of competition, namely, the chance to play one buyer off against others, in an attempt to increase the bid. ${ }^{18}$

15. Bradley, Desai \& Kim, Synergistic Gains from Corporate Acquisitions and Their Division Between the Stockholders of Target and Acquiring Firms, 21 J. Fin. ECON. 3, 21-25 (1988).

16. Economists prefer the ex ante perspective, but the ex post perspective is important nonetheless for three reasons. First, it provides a sense of what is at stake in a dispute, and who, if anyone, is hurt. If the damages from an ex post view are minimal, it is pointless to consider another perspective. Second, in deciding cases, courts have before them parties in real, ex post situations. In trying to do justice, courts must thus consider the ex post outcome. The ex ante perspective enters in only when the court considers the potential effects of its decision on future behavior. Finally, the perennial oscillation between ex ante and ex post perspectives suggests that one cannot choose either view exclusively, and that the two views are intimately linked. See Rose, Crystals and Mud in Property Law, 40 STAN. L. REv. 577 (1988).

17. Dispersed shareholders of a pubhicly held corporation are particularly vulnerable because of their coordination problems. If such bidding agreements are permitted, then the "auctioneering rule" proposed by Professors Bebchuk and Gilson-restricting management to seeking competing bids in the face of a hostile offer-may not proteet dispersed shareholders faced with a distorted choice. See Bebchuk, Facilitating Competing Tender Offers, supra note 12; Bebchuk, Reply and Extension, supra note 12; Gilson, Seeking Competitive Bids, supra note 12; Gilson, Structural Approach, supra note 12.

18. The legal structure within which bargaining oceurs influences the ultimate allocation of gains between buyers and sellers by affectimg the relative bargaining leverage among the parties to the transaction. See, e.g., Cooter, Marks \& Mnookin, Bargaining in the Shadow of the Law: $A$ Testable Model of Strategic Behavior, 11 J. LEgaL STUD. 225, 247 (1982); Mnookin \& Kornhauser, Bargaining in the Shadow of the Law: The Case of Divorce, 88 YALE L.J. 950, 968 (1979). The nature of the regulation of tender offers, the role prescribed for target management, the legality of bidding agreements, and the possibility of coordination among shareholders all affect the relative bargaining positions of bidders and targets, and the resulting allocation of gains from both negotiated and hostile changes of control. Leebron, Games Corporations Play: A Theory of Tender Offers, 61 N.Y.U. L. REv. 153, 156, 178, 199 (1986); see also Asquith, Brnner \& Mullins, The Gains to Bidding Firms from Merger, 11 J. FIN. EcoN. 121, 132 (1983); Haddock, Macey \& McChesney, Property Rights in Assets and Resistance to Tender Offers, 73 VA. L. REV. 701 (1987); Jarrell \& Bradley, The Economic Effects of Federal and State Regulation of Cash Tender Offers, 23 J.L. \& ECON. 371, 388-89, 394-95 (1980); Schipper \& Thompson, Evidence on the Capitalized Value of Merger Activity for Acquiring Firms, 11 J. FIN. EcoN. 85, 109-10 (1983); Schipper \& Thompson, The Impact of Merger-Related Regulations on the Shareholders of Acquiring Firms, 21 J. ACCT. RES. 184, 215-16 (1983).

From a theoretical perspective, the situation may be modeled as a contest to determine which player is the "veto player" in a "veto game." In a veto game, participation of one player (the veto player) is necessary to produce the gains, but only some of the other players (the "non-veto players") need to reach an agreement with the veto player, and no single one of those other players is necessary. Leebron, supra, at 190. Both theoretical analysis and empirical evidence indicates that in a veto game, most if not all of the gains from the transaction will be allocated to the veto player. $I d$. (citing Murnighan \& Roth, Effects of Group Size and Communications, 39 Personaliry \& Soc. Psychology 92, 93, 97 (1980)). Thus each player will strive to be the veto player.

The single-bidder tender offer, where neither management nor shareholders can exercise an effective veto because of coordination problems, presents a veto game with the bidder as the veto player: No gains result unless the bidder participates, and none of the shareholders is essential. Prior to enactment of the Williams Act and its requirement of a 20-day tender period-a period 
Comparing the battle for Federated Department Stores with the one for RJR Nabisco illustrates the magnitude of this effect. In the Federated battle, the bidders agreed to stop bidding against each other when the high bid was $\$ 75.51$ per share, and then lowered the bid to $\$ 73.50$. By contrast, in the battle for RJR Nabisco, the bidders unsuccessfully attempted to work out an agreement to stop the bidding when the face amount of the bid was at $\$ 90$ per share ( $\$ 20.6$ billion). ${ }^{19}$ Subsequently, through able negotiating by the RJR Nabisco special committee, the bidders were played off agamst each other, and the bidding escalated to the ultimate purchase price of $\$ 109$ per share ( $\$ 25.07$ billion). ${ }^{20}$ The bidders' failure to reach an agreement to halt the bidding made the RJR Nabisco shareholders more than $\$ 4$ billion richer. By contrast, the Federated shareholders lost at least $\$ 178$ million and probably more by virtue of the bidding agreement.

But while the ex post distributional effect of bidding agreenents is clear, the situation is less certain from an ex ante perspective. Without the possibility of reaching agreements with others, potential bidders have less incentive to enter the bidding contest, which entails sunk costs, such as research expenses and legal and investment banking fees. ${ }^{21}$ The question thus arises whether restricting bidding agreements places shareholders better off ex ante since the restrictions, although increasing the premiums paid im contested tender offers, may decrease the incidence of bids and therefore the number of contested tender offers. ${ }^{22}$

during which management can implement defenses, exhort shareholders, and solicit competing bids-"Saturday night special" tender offers, that is, surprise tender offers that closed within a few days, placed the bidder in the role of veto player. Not surprisingly, the Williams Act substantially increased the magnitude of tender offer premiums. See Jarrell \& Bradley, supra, at 372.

By contrast, once a competing bidder has entered the fray, the target company becomes the veto player. While some gains may arise without the target board's agreement, its choice as between competing bidders is often dispositive. Once an auction starts, neither bidder is truly essential to a deal. Add to this the bidders' desire to make a deal, as contrasted with target management's willingness or preference to continue independent, and it is likely that where there are competing bids, the bulk of the gains will be allocated to the target. Leebron, supra, at 183, 190. As Professor Leebron points out, this analysis suggests that golden parachutes, by reducing management's desire to remain independent, may actually result in lower premiums to the shareholders. Id.

19. Wall St. J., Oct. 27, 1988, at A3, col. 1.

20. Wall St. J., Dec. 2, 1988, at Al, col. 6. These were the face amounts of the bids, which were each a combination of cash and notes. The actual market value of each bid was somewhat lower.

21. If bidding were costless, then bidders would bid whether or not bidding agreements were permitted, so long as their valuation of the target was higher than the current bid.

22. A similar question was at the heart of the exchange between Judge Easterbrook and Professor Fischel, and Professors Bebchuk and Gilson over whether target management should be permitted to instigate an auction in the face of a tender offer. Compare Easterbrook \& Fischel, Proper Role, supra note 12, at 1177-82 and Easterbrook \& Fischel, Auctions and Sunk Costs, supra note 12, at 7-9 with Bebchuk, Facilitating Competing Tender Offers, supra note 12, at 1034-41 and Bebchuk, Reply and Extension, supra note 12, at 30-39 and Gilson, Seeking Competitive Bids, supra note 12, at 52-62. Easterbrook and Fischel argued that, ex ante, shareholders would prefer a rule of 
The extent to which applying the antitrust laws to the market for control will reduce incentives to bid should not, however, be exaggerated. First, ample incentives to bid already exist without the additional incentive provided by bidding agreements. Bidders can and often do purchase a substantial block of shares prior to announcing their bid. Such low price purchases allow bidders to hedge, effectively reducing the costs of an unsuccessful bid. Indeed, bidders can (and do) realize considerable profits when they are unsuccessful in securing control because of a higher, coinpeting offer. ${ }^{23}$

Second, even though agreements among bidders are currently free from antitrust attack, such agreeinents are not always made. Many contests for control do not end as the result of agreements among the bidders. In deciding whether to bid, a potential bidder already must substantially discount the value of a possible bidding agreement. A rule prohibiting bidding agreements would merely reduce the probability of such arrangements to almost zero.

Third, while decreasing incentives to bid, the higher premiums stemming from competition increase the incentives for targets and intermediaries to search out the highest bidders. ${ }^{24}$ As a result, any reduction in bidders' incentive will be offset, to some extent, by the increased incentives provided to targets and intermediaries.

Finally, if an inability to make bidding agreennents would in fact discourage tender offers to an extent that would disadvantage shareholders, an alternative solution is readily available that would leave competition for control fully protected: The incentive to bid can be fine-tuned simply by adjusting the trigger for disclosure obligations. ${ }^{25}$ By increasing the number of shares that a bidder can purchase before disclosing its

management passivity because it would maximize the number of tender offers, even though it might result in lower premiums. Gilson and Bebchuk each responded that increased premiums resulting from competing tender offers would not significantly reduce the incidence of bids. There, as here, the question is an empirical one. Coffee, Regulating the Market for Corporate Control: A Critical Assessment of the Tender Offer's Role in Corporate Governance, 84 CoLUM. L. REV. 1145, 1175-83 (1984).

' 23. See Bebchuk, Facilitating Competing Tender Offers, supra note 12, at 31; Gilson, Structural Approach, supra note 12, at 871.

24. See Bebchuk, Reply and Extension, supra note 12, at 30-39; Gilson, Seeking Competitive Bids, supra note 12 , at $52-62$.

25. The gross returns that an unsuccessful bidder can make in bidding for a company that another firm acquires are equal to $A Y P$, where $A$ is the number of shares that can be acquired before any disclosure is made, $Y$ is the price paid per share, and $P$ is the premium, expressed as a percentage, which the unsuccessful bidder receives when selling out. If one can accumulate $5 \%$ of a company with I million shares before disclosing one's bid (or 50,000 shares), and if the price per share is $\$ 100$ and the premium paid by the successful bidder is $50 \%$ higher, the gain to the unsuccessful bidder is $50,000 \times \$ 100 \times 0.50$, or $\$ 2.5$ million. If Congress or the SEC determines that $\$ 2.5$ million provides an insufficient incentive to bid, then it can increase that incentive by adjusting $A$, which is a function of regulation, while $Y$ and $P$ are not. 
holdings, the profits from hedging can be increased to provide optimal bidding imcentives.

\section{Allocational Effects}

The second perspective from which to analyze bidding agreements is that of allocational efficiency. Bidding agreements threaten allocational efficiency in two ways. First, allocational efficiency is reduced if the prevailing bidder, because of a bidding agreement, is not the highest valuing user. Second, allocational efficiency is reduced if, as a result of bidding agreements, socially desirable investment in companies is discouraged, or socially wasteful investment is encouraged.

\section{a. Allocating Control to the Highest Valuing User}

In the paradigmatic battle for corporate control, a number of different groups seek to control the target corporation: incumbent management, Bidder $A$, and Bidder $B$. From the perspective of allocational efficiency, the optimal result is one where the competing management group best able to utilize the corporate assets prevails. If one assumes that, as a general matter, the most accurate and convenient measure of the ability to put soinething to a valuable use is the willmgness to pay for it, ${ }^{26}$ one can assume that where there are competing bids for a good or service, the highest bidder is also the highest valuing user. ${ }^{27}$

Bidding agreements threaten allocational efficiency in the market for

26. Easterbrook \& Fischel, Proper Role, supra note 12, at 1176 n.40; Gilson, Structural Approach, supra note 12, at 872 . Of course, this measure is imperfect: People may still overpay.

27. This is necessarily true if and only if one assumes that markets are perfectly efficient, and no uncertainty exists as to the value of the corporate assets to any one of the competing bidders. In the real world of imperfect markets, however, many factors may keep the highest valuing user from making the highest bid. For example, the winning bidder (the "bluffer") may have convinced a bidder actually willing to offer the highest price that he, the bluffer, was willing to top that bid; since entering auctions is often costly, the true highest valuing user thus chooses not to bid. Or, again, the auction may be poorly run so that the highest valuing user does not have an opportunity to bid. Alternatively, external factors such as tax consequences and market power concerns may favor one bidder over another. And finally, imperfections in the capital markets may preclude the highest valuing user from securing financing for its bid. The list can be extended almost indefinitely.

Can the general principle that the high bidder is the highest valuing user be applied to the market for corporate control? It depends. If one views takeovers as generally occurring when the buyer is better able to utilize the assets than the target management, or where combining the enterprises yields synergies, then it follows that one may presume that the high bidder is the highest valuing user. If, on the other hand, one views takeovers as predominantly driven by managerial hubris or external, non-efficiency enhancing considerations like tax incentives or pursuit of market power, then there seems to be no particular reason to suppose that the high bidder for a company is the bidder most able to utilize the corporate assets.

This second situation presents a difficulty. If one believes that the market for corporate control is so inefficient that one cannot rely on it to determine who is the optimal user, then how can one know whether restricting bidding agreements will make it more or less efficient? The answer, of course, is that one cannot know. But it is equally true that skepticism about the efficiency of thc market for corporate control does not provide an argument for permitting bidding agreements: 
corporate control in two ways. First, bidding agreements inay discourage higher valuing third parties froin entering the contest for control. Second, the bidders inay agree to an outcome that is allocationally inferior to the one that would have einerged through coinpetition.

\section{i. Effects of Bidding Agreements on Potential Bidders}

As a battle for control progresses, the incentives for third parties to enter the bidding decrease, while the sunk costs of entering remain about the same. This occurs for two reasons. First, the potential gain of winning, measured by the difference between the value of the coinpany to a potential bidder and the acquisition price, decreases as the bids for the company increase. Second, the bidder's ability to profit by accumulating lower-priced stock that it can tender into a successful offer is reduced. ${ }^{28}$ Thus, as the bidding escalates, the incentives for third parties to bid decline, even if, in fact, a third party is the highest valuing user.

A further practical effect of bidding agreements exacerbates these declining incentives to enter the bidding contest. Once two or inore bidders enter into a bidding agreeinent, they are able to pool their strengths against the remaining bidder or any other bidder who enters the fray. Consider the battle for Federated Department Stores discussed above. Once Canpeau and Macy's combined forces, any additional bidders faced a discouraging prospect. To prevail, a third party would have had to beat a well-financed group that had a clear informational advantage and a tender offer that would expire before any bid by a new entrant could close. The prospect of competing against such an adversary would likely discourage even higher valuing bidders, especially since they already faced reduced incentives to bid. As a result, bidding agreements may dissuade higher valuing third parties from entering the contest at all.

\section{ii. Efficient Allocation Among Bidders}

In addition to the effects on third parties, private agreements ainong

There is no reason to think that bidding agreements limit the effects of managerial hubris or tax incentives on takeovers.

Accordingly, for purposes of this Section, I will generally assume that, on the whole, allocational efficiency is increased if a target is acquired by the bidder willing to pay the most for it. See Coffee, supra note 22, at 1280 (competitive auction market should, in theory, direct assets to their highest valued use); see also Bebchuk, Reply and Extension, supra note 12, at 39; Bebchuk, Toward Undistorted Choice and Equal Treatment in Corporate Takeovers, 98 HARv. L. REV. 1693, 1802-03 app. B (1985) [hereinafter Bebchuk, Undistorted Choice]. But see Lowenstein, Pruning Deadwood in Hostile Takeovers: A Proposal for Legislation, 83 Colum. L. REv. 249 (1983).

28. But the opportunity to profit is not eliminated. Even a late-entering bidder can still profit by the difference between the cost of purchasing stock and the winning bid. The bidder knows that it will bid higher than the current market price, and that the winning bid will be at least as high as the bidder's offer. 
bidders may be less allocationally efficient than competition between bidders. Consider the following hypothetical: Bidder $A$ makes a bid for Target Company $T$. Shortly thereafter, Bidder $B$ makes a competing bid. $A$ and $B$ make additional bids. No other companies express any interest in acquiring $T$. At this point, $A$ approaches $B$ and says, "Why are we knocking each other out? If you will drop out of the bidding, I will pay you $\$ 3$ million." $B$ agrees. From an allocational perspective, the bidding agreement between $A$ and $B$ substitutes a private agreement for a market determination of who is the highest valuing user of $T .^{29}$

If one assumes that bidders are profit maximizers and have perfect information, agreements among bidders may be more allocationally efficient than coinpetitive bidding. ${ }^{30}$ The problem, however, is that $A$ and $B$ are unlikely to know which, among themselves, is the highest valuing user. Thus, a private bidding agreeinent between them may fail to ensure that the highest valuing user prevails.

First, $A$ and $B$ may sincerely not know which of them would bid the most for $T$. In a thick, competitive market, valuation does not pose a problem. In a competitive market characterized by inany buyers, many sellers, and a fungible commodity, ${ }^{31}$ both buyers and sellers are "price takers," and the price is typically well known and well defined. ${ }^{32}$

In thin markets, however, this is not the case. Consider the market for fine art in which each piece is essentially unique. For the better works, there are likely to be very few buyers at any given time; likewise, for a buyer interested in a particular sort of painting, there are likely to be very few sellers at any given time. When selling an authenticated Van Gogh, one knows what one has but one does not know how others value it. Appraisers can predict what the painting will hikely bring by reviewing past sales and comparing the painting to others that have been sold. But appraisers can give no more than an estimate, and often their estimate is very far off. ${ }^{33}$ The valuation of an authenticated Van Gogh is

29. The potential allocational inefficiency arising from bidding agreements is limited by competition from third parties. As discussed above, however, bidding agreements may discourage higher valuing third parties from entering. See supra text accompanying notes 21-22. Moreover, if $A$ and $B$ are the two highest valuing users, third parties will not affect whether $A$ or $B$ ends up with control, but only the price paid for $T$.

30. Where each bidder is primarily interested in different parts of a target, a bidding agreement allows the bidders to divide the target without incurring the transaction costs and risks of buying the whole target and subsequently selling off unwanted divisions. Even where the agreement is a straight payment between bidders, one might suppose that the bargaining between the bidders will yield an optimal allocation of control. Thus if $A$ values $T$ more highly than $B, A$ may be willing to pay $B$ more to drop out than $B$ will pay $A$.

31. F. Scherer, Industrial Market Structure and Economic Performance 9-12 (2d ed. 1980).

32. For example, wheat farmers and buyers know the price of wheat from looking at the transactions on the Chicago Board of Trade.

33. See, e.g., N.Y. Times, Mar. 31, 1987, at Al, col. 14 (Van Gogh's Sunflowers sold at auction 
thus an example of "preference uncertainty."34

The market for corporate control is much more similar to the market for fine art than to a thick competitive market, such as the market for wheat. Companies, like paimtings, are essentially umique. ${ }^{35}$ Very few comparable companies are sold under comparable conditions. For any given company at any given time, there are likely to be relatively few prospective buyers; and for any given buyer at any given time, there are hikely to be relatively few potential targets. Moreover, a corporation may be worth differing amounts to different bidders. ${ }^{36}$ Corporations, like fine art, thus present a problem of preference uncertainty. ${ }^{37}$ Where, as in the market for corporate control, there is preference uncertainty, auctions and other forms of competitive bidding are important and commonly used methods of valuation, because they are a direct test of what the market will pay. ${ }^{38}$

for $\$ 39.85$ million; previous estimate was "in excess of $\$ 15$ million."); N.Y. Times, Mar. 27, 1987, at C28, col. 5 (same).

34. There may also be "quality uncertainty."

35. Leebron, supra note 18, at 165-66.

36. Coffee, supra note 22, at $1166-67$.

Companies differ from works of art in two respects. First, unlike paintings, a company provides a stream of earnings that establishes one basis for estimating its value. Second, individual shares and small blocks of shares of companies are traded on public exchanges. Each of these differences makes it easier to estimate the market value of a corporation as a whole, but neither provides any certainty. First, while in theory it may be true that the value of a company is its stream of future earnings discounted to present value, one can only estimate a company's stream of future earnings. Moreover, the choice of the appropriate discount rate is a speculation based on the prevailing interest rates, the riskiness of the stream of future earnings, and the general condition of the economy.

Second, the market price of individual shares or small blocks of shares of a company does not directly translate into a value for the company as a whole. This difference is dramatically demonstrated in the real world marketplace: Typically, the price paid for a company in a tender offer is approximately $50 \%$ above the prevailing market price before the offer was announced. See, e.g., Smith v. Van Gorkom, 488 A.2d 858 (Del. 1985).

Finally, the actual valuation techniques used by investment bankers reflect the inadequacy of earnings projections and market price for valuing the corporation as a whole. Investment bankers valuing a corporation will generally consider a variety of valuation techniques. These include discounting the projected cash flow of the firm, comparing the firm to comparable or nearly comparable firms on the basis of a range of financial ratios, valuing the firm by reference to benchmark financial ratios derived from the sale of comparable companies, and reviewing the trading history of its shares. None of these methods is precise, and none yields more than an estimate of the value of the company, defined as what a willing buyer would pay in an arm's length transaction under appropriate conditions (as opposed to a distress sale).

37. Corporations also present a problem of quality uncertainty. When an acquirer bids on a target, it cannot be quite sure what it is getting. Although the acquirer has information from public filings, industry research, and possibly even from the target itself, in the final analysis, the acquirer cannot know what it has bought until it has actually bought it.

38. Engelbrecht-Wiggans, An Introduction to the Theory of Bidding for a Single Object, in Auctions, Bidding, AND CONTRACting: Uses AND THEORY 53, 57-59 (Engelbrecht-Wiggans, Shubik \& Stark eds. 1983); Leebron, supra note 18, at 192. Thus, for example, investment bankers valuing a corporation will often perform a market test in addition to using other valuation techniques. In some circumstances, such as when a bidder makes a very attractive offer that is open 
Second, in the normal competitive bidding situation, $A$ and $B$ each have a strategic incentive to bluff-to mislead the other as to their valuations of $T{ }^{39}$ Because $A$ and $B$ are unlikely to know which, between theinselves, is the highest valuing user, a private bidding agreement between them may fail to ensure that the highest valuing user prevails.

Moreover, because of differing aversions to risk, bargaining among bidders may not yield as allocationally efficient an outcome as competition between bidders would. That is, the bidder who actually places the highest value on the target may opt mstead for the certain payment from the other bidder, even where that payment is less than the difference between the value it actually places on the target and the ultimate purchase price. Depending upon the risk preferences of the two bidders, the potential risks and returns confronting bidders may result in the lower valumg bidder gaining control. ${ }^{40}$

for only a short time, a market test is not possible, and the investment bankers must rely on other valuation techniques. But where there is sufficient tinie, the market test is superior to any investment banking analysis.

39. Note, for example, the battle for RJR Nabisco. Kohlberg, Kravis \& Roberts ("KKR") made a low bid of $\$ 94$ per share while the management group bid $\$ 100$ per share in what was to be the final round of bidding. KKR then complained that it had not been given the information that had been available to the management group. Subsequently, by means of judicious leaks, KKR apparently sought to convince the management group that if they made another bid, it would not be materially higher than $\$ 94$. In the next round, however, and apparently to the surprise of the management group, KKR took the lead and the momentum by offering $\$ 103$ per share, while management only increased its offer to $\$ 101$ per share. See Buy-Out Bluff: How Underdog KKR Won RJR Nabisco Without Highest Bid, Wall St. J., Dec. 2, 1988, at A1, col. 6.

40. Suppose that $T$ is currently trading for $\$ 25$ per share, and that there are 1 million shares outstanding, thus yielding a market valuation for $T$ of $\$ 25$ million. Suppose that $A$ values $T$ at $\$ 50$ million, $B$ values $T$ at $\$ 45$ million, and both $A$ and $B$ have incurred $\$ 1$ million in expenses for legal and investment banking services. Finally, suppose that an auction has started in which $A$ and $B$ are the sole bidders, and they have bid the price of $T$ up to $\$ 40$ per share.

What array of risks and returns does $A$ face? If $B$ values $T$ more highly than $A$ does, then $B$ will get $T$, and $A$ will get nothing and be out its $\$ 1$ million in expenses. On the other hand, if $A$ is the highest valuing user of $T$, then $A$ will get $T$ for $\$ 50$ million or less. Even if $A$ wins the auction, it will not necessarily profit: it still runs the risk of overpaying. A bidder will bid up to its full valuation of $T$, if necessary, even if it has incurred substantial nonrefundable costs of bidding. To illustrate, suppose that the last bid for $T$ is $\$ 49 ; A$ values $T$ at $\$ 50$ and has already spent $\$ 1$ per share on bidding costs. If $A$ drops out at $\$ 49, A$ is down $\$ 1$ per share. If, on the other hand, $A$ bids $\$ 49.50$ and gets $T, A$ is only down $\$ 0.50$ per share $(T$ costs $A \$ 49.50+\$ 1.00$, or $\$ 50.50$ per share, while it is only worth $\$ 50$ to $A$ ). $A$ will therefore bid $\$ 49.50$, and, by parallel reasoning, will continue bidding up to $\$ 50$. For a general analysis of the effects of entrance fees and other means of making bidders pay, see Maskin \& Riley, The Gains to Making Losers Pay in High-Bid Auctions, in Auctions, BIDDING, AND CONTRACTING: USES AND ThEoRY, supra note 38, at 205. For the modeling of an analogous situation, see Shubik, The Dollar Auction Game, 15 J. CoNflict Resolution 109 (1971).

Now suppose, as above, that $B$ offers $A \$ 3$ million to stop bidding. How does this shift $A$ 's view of the world? If $A$ accepts the offer, then $A$ ends up $\$ 2$ million ahead on the deal (\$3 million less $\$ 1$ million in expenses) with no risk whatsoever. If, however, $A$ continues in the auction, $A$ faces precisely the same risks as it did before $B$ made the offer: $A$ may get $T$ at a profitablc price, it may not get anything and be out its expenses, or it may overpay for $T$. Under such circumstances, depending on how certain $A$ is of its valuation of $T$, as well as $A$ 's aversion to risk, $A$ might very well decide that a sure $\$ 2$ million is preferable to the uncertainty of continuing in the auction. 
In addition, unlike a coinpetitive auction, bargaining between bidders is susceptible to corruption because of the communications and negotiations between the competing bidders. For exainple, Bidder $B$ (the lower valuing user) may pay off the managers of Bidder $A$ to induce them to withdraw $A$ from the bidding. Under these circuinstances, even though $A$ may be better able to manage $T$ than $B$ is, the benefits to $A$ 's management froin not bidding inay outweigh the benefits to it froin acquiring $T$, and $A$ 's management might therefore withdraw $A$ from the auction. In a competitive auction where bidders operate imdependently, such agreements are less likely to be inade, and, if made, are harder to disguise.

Fmally, bargaining among bidders is soinewhat more susceptible to cross-transactional agreements than a competitive auction is. For example, $A$ and $B$ might agree that because $A$ got the last deal, $A$ will defer to $B$ in the present deal. These sorts of agreements, while perfectly natural in an ongoing relationship among bidders, are unlikely to bear more than a rough relationship to the relative value each bidder places on a target. ${ }^{41}$

\section{b. Potential Allocational Inefficiencies from the Distributional Effects}

To the extent that bidding agreeinents allow bidders to limit the price paid for targets, they may create additional allocational inefficiencies. First, by lowering premiums, biddmg agreeinents reduce owners' incentives to pursue efficiency gams and to build up companies. ${ }^{42}$ For example, a start-up company inay not do what it does best, say, produce a new and valuable coinputer prograin, if it cannot rely on a competitive market for control when acquisition by a larger company to inarket and distribute the program is appropriate. ${ }^{43}$

Second, the transfer of wealth from target shareholders to acquiring shareholders may lead acquirers to invest resources in establishing and pohicing bidding agreements, while encouraging targets to invest resources im preventing bidding agreeinents, or in soliciting additional bids. The expenditure of these resources imposes an additional cost on

41. In a world without transaction costs and in which management acts as a perfect agent for its shareholders, any initial allocational inefficiencies owing either to bidding agreements or the prohibition of bidding agreements might work themselves out through subsequent reallocations. In the real world, of course, neither condition holds.

42. See Leebron, supra note 18, at 209-12. The importance of this should not be underestimated. One version of the "American Dream" is to start a company, build it into a respectable organization, and then, because one's children have decided to become doctors or lawyers, sell it to a larger company and retire to the good life. Indeed, one of the costs of overactive enforcement of section 7 of the Clayton Act is the dilution of these incentives. See L. Sullivan, HANDBOOK OF THE LAW OF ANTTTRUST § 204, at 614-15 (1977).

43. Haddock, Macey \& McChesney, supra note 18, at 709-11; see, e.g., Gupta, Biotech StartUps Are Increasingly Bred Just to Be Sold, Wall St. J., July 19, 1989, at B2, col. 3. 
society. ${ }^{44}$

Finally, a perception that tender offers effectuate a transfer of wealth from targets to acquirers may itself tend to jeopardize allocational efficiency. Such a perception would support efforts to prohibit or severely restrict tender offers and to allow target management unlimited discretion to block such offers. To the extent that a significant proportion of takeovers do enhance efficiency, such measures may impose unnecessary costs on society.

\section{B. The Importance of Protecting Competition for Control, Regardless of One's Views Concerning Takeovers}

The social utility of takeovers is a hotly debated question. There are four main views of hostile takeovers. Some argue that takeovers enhance efficiency, either by replacing bad management with good, or by creating synergies by consolidating complementary operations. ${ }^{45}$ From this perspective, a competitive market for control plays an important role in the existing structure of corporate law: It helps protect shareholders from overreaching or underperformance by their managers. ${ }^{46}$ If corporate assets are poorly managed, a gap opens between their value under the control of incumbent management and their value in the control of a third party. That difference provides an incentive for third parties to acquire the corporation and displace incumbent management. The possibility of such a takeover acts as a spur to all managers and provides a check on the wide discretion granted management in the performance of its duties. This is the "efficiency hypothesis."

In contrast to this sanguine view, others are more skeptical, arguing that takeovers are but the latest manifestation of "managerialism" and empire building. Proponents of this view attribute expansion by the

44. See R. POSNER, Economic ANALYSIS OF LAw 254-59 (1986); R. Posner, supra note 14, at 8-18. In general, the allocative costs, in addition to the dead weight welfare loss (the "welfare triangle") include (1) expenditures made by firms to gain or protect market power ("rent seeking"), and (2) wasteful failure to reduce costs that could and would be reduced under the spur of greater competition ("x-inefficiencies"). Sullivan, supra note 13, at 840 n.29.

The point is somewhat more clear in the analogous context of theft. R. POSNER, Economic ANALYSIS OF LAW, supra, at 258. Theft, on its face, is neutral from the perspective of allocational efficiency. It is "merely" a wealth transfer. But that view ignores its real cost to society: If theft were permitted, thieves would expend resources on stealing goods, while homeowners might increase their efforts to prevent thefts. These costs make the wealth transfer resulting from theft allocationally significant, as the resources expended in planning and preventing burglaries could be better allocated to other uses.

45. See, e.g., R. Gilson, The LAw and Finance of Corporate AcQuisitions chs. 10-11 (1986); Easterbrook \& Fischel, Auctions and Sunk Costs, supra note 12, at 1; Easterbrook \& Fischel, Proper Role, supra note 12, at 1169, 1173; Manne, Mergers and the Market for Corporate Control, 73 J. Pol. ECON. 110 (1965).

46. Coffee, supra note 22, at 1163-66, 1199-1215; Easterbrook \& Fischel, Proper Role, supra note 12, at 1173; Gilson, Structural Approach, supra note 12, at 841-45. 
bidder's managers to hubris, or a desire to increase the size of their firm, and thereby increase their own salaries, perquisites, and prestige, without necessarily increasing the profitability of their firm. ${ }^{47}$ This view, (the "hubris hypothesis") is a version of the more general hypothesis that bidders systematically overpay for targets (the "overpayment hypothesis")..$^{48}$

Others argue that takeovers occur because the widely dispersed shareholders of a publicly held corporation face a collective choice dilemma: They cannot resist a tender offer at an above market price, even though the price offered is below the value of the company to the owners of a majority of the shares. ${ }^{49}$ This view is the "distorted choice hypothesis."

Finally, some argue that takeovers are driven by features independent of and external to the target firm's performance, such as expansion of market power, tax advantages, or systematic undervaluation by the stock market with resulting possibilities for arbitrage between the market for shares and the market for companies. ${ }^{50}$

These four accounts overlap, and many commentators accept more than one analysis. ${ }^{51}$ Depending on which accounts one accepts, and in what proportions, one comes to different conclusions on whether takeovers are, on balance, good or bad for society. Yet, regardless of how one resolves these issues, antitrust principles should be applied to the market for control. Failure to protect competition will not ameliorate problems caused by hostile takeovers, and may, in fact, exacerbate them. Furthermore, even if one is skeptical of the virtues of hostile tender offers, believing perhaps that hostile takeovers are a clear loss for society, one should not want to make it easier for bidders to acquire targets: Yet that is the effect of permitting bidders to agree not to compete.

Taking the competing views in order, if one accepts the efficiency hypothesis, that is, the view that competition in the market for control is good because a competitive market for control monitors and disciplines incumbent management and reallocates underutilized corporate assets to higher valuing users, ${ }^{52}$ then one should also believe that that competition should be protected. Indeed, those commentators who adopt this view

47. See, e.g., Coffee, supra note 22, at 1167-69; Roll, The Hubris Hypothesis of Corporate Takeovers, 59 J. Bus. 197 (1986).

48. Black, Overpayment in Takeovers, 41 STAN. L. REv. 597 (1989).

49. See Bebchuk, Undistorted Choice, supra note 27, at 1717-33; Lowenstein, supra note 27, at 307-09.

50. See, e.g., Bebchuk, Facilitating Competing Tender Offers, supra note 12, at 1031-32 (expansion of market power and tax advantages); Coffee, supra note 22, at 1170-73 (stock market undervaluation); Leebron, supra note 18, at 165 \& n.50 (same).

51. See, e.g., Bebchuk, Undistorted Choice, supra note 27; Coffee, supra note 22.

52. See supra text accompanying notes $45-46$. 
condemn management defensive tactics because they interfere with competition for control. ${ }^{53}$

Second, suppose that one assumes that successful bidders systematically overpay, ${ }^{54}$ either out of hubris, or because of the winner's curse, ${ }^{55}$ or just because of miscalculation or ineptness. This assumption likewise provides no reason to allow bidders to collude. Antitrust does not accept the reasonableness of a price, or the "danger" of "ruinous competition," as a justification for price fixing. ${ }^{56}$ In every other auction or quasi-auction market, bidders fend for themselves, even if it means that they overpay.

The risk of overpayment should be of no greater concern in the market for control than in any other market. Bidders have a clear financial mcentive to modify their biddmg practices to avoid overpaying. In addition, the problem is self limiting: Those bidders who consistently overpay will tend to disappear. Indeed, if the hubris hypothesis is correct, protectimg competition may be especially important because it limits acquisitions at least to the extent of requiring that hubris-filled managers pay the competitive price for their acquisitions. ${ }^{57}$ Moreover, assuming that hubris is rather evenly distributed among managers, competition among bidders should tend to yield the most efficient allocation of control: The hubris of the competing bidders will tend to cancel out and the difference in bids will tend to reflect the difference in the bidders' ability to utilize the underlymg assets. ${ }^{58}$

\footnotetext{
53. See, e.g., Easterbrook and Fischel, Proper Role, supra note 13; Bebchuk, Facilitating Competing Tender Offers, supra note 12; Gilson, Structural Approach, supra notc 12.

54. Black, supra note 48.

55. The "winner's curse" occurs because a bidder is more likely to win an auction when it overestimates the value of the object than when it underestimates the value. See, e.g., Milgrom, Private Information in an Auctionlike Securities Market, in AUCTIONS, BIDDING, AND CONTRACTING: USES AND THEORY, supra note 38, at 140 .

56. See, e.g., United States v. Socony-Vacuum Oil Co., 310 U.S. 150, 220-24 (1940). As Justice Douglas held:

Congress has not left with us the determination of whether or not particular price-fixing schemes are wise or unwise, healthy or destructive. It has not permitted the agc-old cry of ruinous competition and competitive evils to be a defense to price-fixing conspiracies. It has no more allowed genuine or fancied competitive abuses as a legal justification for such schemes than it has the good intentions of the members of the combination. If such a shift is to be made, it must be done by the Congress. Certainly Congress has not left us with any such choice. . . . Whatever may be [the oil industry's] peculiar problems and characteristics, the Sherman Act, so far as price-fixing agreements are concerned, establishes one uniform rule applicable to all industries alike.
}

Id. at 221-22; see also United States v. Trenton Potteries, 273 U.S. 392, $396-98$ (1927). But see Appalachian Coals, Inc. v. United States, 288 U.S. 344 (1933).

57. Coffee, supra note 22, at 1225.

58. This is an argument against the hubris explanation in general. If one assumes that hubris is fairly evenly distributed among managers of potential targets and potential acquirers, and that substantial financing is available for management buyouts as well as for hostile takeovers, it is hard to see how the hubris hypothesis explains anything. Why is it, in a given case, that one group of hubris-filled managers wins out over another group of hubris-filled managers? 
Finally, if the fundamental assumption of the hubris and overpayment hypotheses is correct, namely, that managers tend to waste their shareholders' money, then allowing bidders to acquire companies for less rather than more does not necessarily make society better off. Under these views, money not spent on acquiring the target will likely be spent on some other, similarly bad investment, rather than being paid out to the shareholders in dividends. ${ }^{59}$

Suppose that one takes the third view, the distorted choice hypothesis, which posits that a substantial number of tender offers succeed, not because the bidder is a higher valumg user than the target shareholders are, but because of the target shareholders' difficulties in coordinating a response. ${ }^{60}$ Under this view, competition in the market for control is crucial because it limits the damage resulting from the collective choice dilemma by allowing shareholders to benefit from competition among bidders. ${ }^{61}$ While such competition does not place target shareholders in as good a bargaining position as a sole owner who can simply refuse to sell, it moves them towards that position, without the agency problems that would arise if incumbent inanagement were allowed to "just say no."62

Finally, to the extent that transactions are driven by tax considerations or pursuit of market power, exempting the basic competitive processes $\dot{m}$ the market for control from antitrust scrutiny would not improve matters. Allowing bidders to collude will not mitigate any distortion that the tax system inay have on the market for control. Indeed, competition, by forcing bidders to pay the competitive price for a coinpany, will tend to discourage tax-driven transactions. Likewise, if takeovers occur out of a pursuit of market power, allowing bidders to collude will encourage rather than discourage such transactions. Finally, if a systematic undervaluation of firms by the stock market drives takeovers, competition among bidders helps mitigate this market failure and thus yields a more allocationally efficient result. ${ }^{63}$

59. Black, supra note 48 at 599-600 (hypothesizing that U.S. Steel's stock did not go down in value when it overpaid for Marathon Oil because investors expected that U.S. Steel would invest earnings in low or no return investments in the steel industry and, as compared to such investments, overpaying for Marathon did not look so bad); Jensen, Agency Costs of Free Cash Flow, Corporate Finance and Takeovers, 76 AM. EcoN. REv. 323, 324, 328 (1986) (Papers and Proceedings of the American Economic Association, 98th Annual Meeting, Dec. 28-30, 1985).

60. Bebchuk, Facilitating Competing Tender Offers, supra note 12, at 1039-40, 1052-54; Bebchuk, Undistorted Choice, supra note 27, at 1717-33.

61. Bebchuk, Facilitating Competing Tender Offers, supra note 12, at 1039-40.

62. See generally TW Servs., Inc. v. SWT Acquisition Corp., 1989 Fed. Sec. L. Rep. (CCH) I 94,334 (Del. Ch. 1989) (discussing whether a board should be allowed to adopt a poison pill rights plan to prevent any bid from succeeding where the board has determined in good faith that the target company should not be restructured or sold).

63. In addition, as Professor Coffec points out, the higher premiums that result from competitive bidding may have other salutary effects. First, the higher premiums are bikely to 
At minimum, each of these differing accounts of takeovers is consistent with the notion that competition in the market for corporate control should be protected. As the law currently stands, however, there exists no regulatory vehicle to protect such competition systematically. State corporate law, the basic source for corporate regulation, primarily concerns itself with corporate governance: what powers are exercised by the board and management, what powers are reserved to the shareholders, what is the relationship between shareholders and the board, for whom is the corporation managed, and so forth. None of these provisions insure a competitive market for corporate control, except in a rather haphazard way through their concern with internal corporate governance. ${ }^{64}$ Moreover, federal securities regulation primarily focuses on the protection of investors and capital markets by means of disclosure requirements. As I show below, the SEC does not, and under its current statutory authority, probably could not regulate bidding agreements. ${ }^{65}$ Therefore, whether tender offers are a great engine of corporate accountability, or simply Wall Street's latest speculative bubble, competition for corporate control should be protected.

II

\section{The Arguments Against Protecting Competition FOR CORPORATE CONTROL}

Two main doctrinal arguments can be leveled against applying antitrust to the market for control. The first branch maintains that, by its terms, section 1 of the Sherman Act ${ }^{66}$ simply does not apply to the market for control. This is the view of the only cases that address the issue. ${ }^{67}$ The second branch concludes that, even if the Sherman Act could have been applied to the market for control, its application to that market has been preempted, or at least made inappropriate, by other regulations. As I will show, however, neither argument succeeds.

minimize inefficient transfers of control by raising the stakes and increasing the costs of mistakes. Second, by generally limiting takeovers to those companies that suffer from severe mismanagement or promise the most significant synergy gains, higher premiums prevent distortions of the market for executive services. A company in need of rehabilitation may have difficulty securing quality management if candidates fear that a tender offer will be launched after the problems have been solved but before the rehabilitation has been translated into higher stock prices. Coffee, supra note 22 , at $1234-38$.

64. See supra note 12; see also Revlon, Inc. v. MacAndrews \& Forbes Holdings, 506 A.2d 173 (Del. 1986).

65. See infra text accompanying notes 136-53.

66. 15 U.S.C. $\$ 1(1988)$.

67. Kalmanovitz v. G. Heileman Brewing Co., 769 F.2d 152, 157 (3d Cir. 1985); Finnegan v. Campeau Corp., 1989-2 Trade Cas. (CCH) \ 68,816 (S.D.N.Y. 1989), appeal docketed, No. 89-9183 (2d Cir. Nov. 27, 1989); Bucher v. Shumway, 452 F. Supp. 1288, 1290-92 (S.D.N.Y. 1978), aff'd mem., 622 F.2d 572 (2d Cir.), cert. denied, 449 U.S. 841 (1980). 


\section{A. The Principal Case: Kalmanovitz v. Heileman}

In Kalmanovitz v. G. Heileman Brewing Co., ${ }^{68}$ the Third Circuit held that because tender offer auctions do not involve "trade or commerce,"69 the Sherman Act, by its terms, does not apply to them. The court's conclusion, however, mistakenly restricts the scope of the Sherman Act contrary to its underlying congressional intent.

Kalmanovitz arose out of the battle for control of Pabst Brewing Company. ${ }^{70}$ Paul Kalmanovitz and Irwin Jacobs, along with several associates, formed a group to bid for Pabst. The Jacobs group already owned more than $14 \%$ of the 8 million shares outstanding. Management opposed their offer and sohicited a competing bid from Heileman Brewing Company, a prospective "white knight," that is, a competmg bidder more acceptable to Pabst's imcumbent management. ${ }^{71}$ The Jacobs group and Heileman both raised their bids several times. After a hearmg im which the district court demed cross-motions to enjom each other's offers, ${ }^{72}$ Heileman announced that it would reduce the number of shares sought to 4.25 million, that 3.9 million shares had already been tendered to it, and that the company would make a further announcement within two days (presumably regarding the price offered per share). ${ }^{73}$

Worried that the Heileman offer would prevail, and that he would be shut out of the proration pool and left holding a vulnerable minority position in Pabst, Jacobs negotiated a deal with Heileman. That deal provided that the Jacobs group would tender its shares into a new Heileman offer, and that Pabst and Heileman would pay Jacobs an additional $\$ 7.5$ million "for expenses." 74

Kalmanovitz objected and, through a wholly owned company, made several independent, competing offers. After Heileman's offer prevailed, Kalmanovitz sued the Jacobs group, Pabst, and Heileman, alleging violations of the federal securities and antitrust laws. Kalmanovitz alleged that the agreement between the Jacobs group and Heileman was an illegal scheme to eliminate competitive bidding and to fix the price of Pabst stock, an agreement for which Jacobs was paid $\$ 7.5$ million. ${ }^{75}$ The district court dismissed Kalmanovitz's antitrust claims under sections 1 and 2 of the Sherman $\mathrm{Act}^{76}$ for failure to state a claim upon which relief

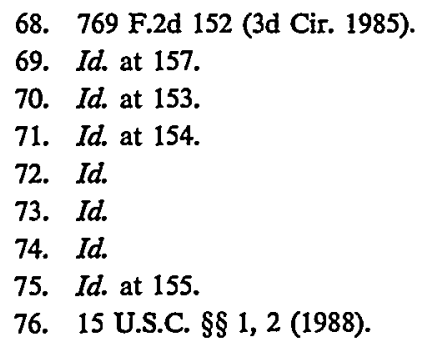


could be granted. ${ }^{77}$

The Court of Appeals for the Third Circuit affirmed. The court argued that one limitation on the broad scope of section 1 of the Sherman Act is that the challenged restraint must involve "trade or commerce" within the meaning of the Act. ${ }^{78}$ Then, quoting Apex Hosiery Co. v. Leader 79 for the proposition that "trade or commerce" means "commercial competition in the marketing of goods or services," 80 the court asked whether the bidding agreement challenged in Kalmanovitz "affects the purchasers or consumers of goods or services." 81 The court concluded that it did not, holding that "the purchase or sale of stock by investors does not fit easily within the definition of goods or services as used by the antitrust laws. A seller of shares of a particular company is not engaged in the business of selling shares as an ongoing trade or business." 82 The court thus concluded that section 1 of the Sherman Act did not apply.

\section{A Critique}

Contrary to the court's opinion-and notably absent from it-the case law indicates that Congress did not intend the phrase "trade or commerce" to limit the scope of the Sherman Act to particular sorts of commercial transactions. Rather, the cases make clear that the terms "trade or commerce" extend to the farthest reach of Congress' constitutional power over commerce. ${ }^{83}$ Congress' power to control commerce clearly includes the power to regulate the market for corporate control. Indeed, 'Congress' power to regulate securities, including its power to enact the

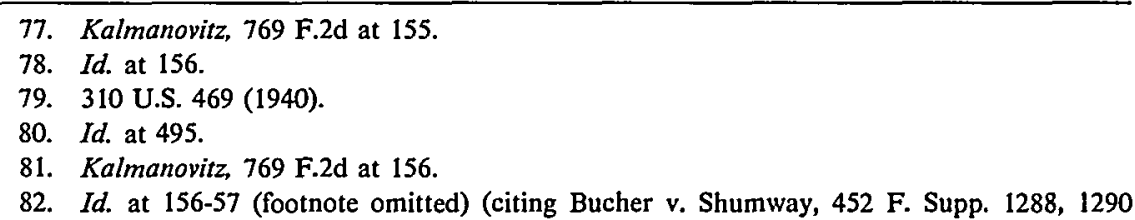
(S.D.N.Y. 1978), aff'd mem., 622 F.2d 572 (2d Cir.), cert. denied, 449 U.S. 841 (1980)).

83. United States v. South-Eastern Underwriters Ass'n, 322 U.S. 533, 557-58 (1944) ("Congress wanted to go to the utmost extent of its Constitutional power in restraining trust and monopoly agreements ....") (citing and quoting legislative history of the Sherman Act); sec also McLain v. Real Estate Bd. of New Orleans, Inc., 444 U.S. 232, 241 (1980) (along with Congress' broad power under the commerce clause, the Court "has often noted the correspondingly broad reach of the Sherman Act"); Hospital Bldg. Co. v. Trustees of Rex Hosp., 425 U.S. 738, 743 n.2 (1976) ("[D]ecisions by this Court have permitted the reach of the Sherman Act to cxpand along with expanding notions of congressional power."); Goldfarb v. Virginia State Bar, 421 U.S. 773, 787 (1975) ("Congress intended to strike as broadly as it could in $\S 1$ of the Sherman Act."); Gulf Oil Corp. v. Copp Paving Co., 419 U.S. 186, 194 (1974) (citing and quoting South-Eastern Underwriters, 322 U.S. at 58); Weiss v. York Hosp., 745 F.2d 786, 824 \& n.63 ("This interstate impact requirement has been construed as an element of both jurisdiction and the substantive offense under the Sherman Act. The inquiry is the same for both elements.") (citations omitted), cert. denicd, 470 U.S. 1060 (1985); Tarleton v. Meharry Medical College, 717 F.2d 1523, 1529 (6th Cir. 1983) ("The reach of the Sherman Act extends as far as Congress' power to regulate interstate commerce."). See gencrally Note, Jurisdiction Under the Sherman Act: A Close Look at the Affects Test, 60 Notre DAme L. REV. 603 (1985) (authored by Jeffrey M. Thompson). 
Williams Act provisions governing tender offers, ${ }^{84}$ springs from its power to regulate interstate commerce under the commerce clause. ${ }^{85}$

Professor Sullivan suggests that the courts have used a practical test to identify commerce: "If there is a dollar to be made, it's trade or commerce." 86 The one exception is baseball, which was not considered commerce at the time of the enactment of the Shernian Act and which, for reasons mysterious only to those ignorant of baseball's grip on the national psyche, has continued to enjoy an exemption. ${ }^{87}$ Under Sullivan's test, tender offer battles are plainly within the scope of the commerce clause and therefore constitute "trade or commerce" under the Shernian Act. There is, as it were, a dollar to be made.

The court's argument also fails on its own ternis. Under Apex Hosiery Co., the crucial question is whether an agreement was imtended to, or had the effect of, fixing price, restricting production, or otherwise controlling a market. ${ }^{88}$ Whether investors in the shares of a particular company are "merchants" in those shares is irrelevant so long as an agreement between the prospective purchasers of those shares was intended to, or had the effect of, fixing the price of those shares. ${ }^{89}$

In addition, the court assumed, without argument or justification, that the crucial inquiry in determining whether the trade or commerce phrase of section 1 was satisfied is whether the seller of the good or service was a merchant with respect to that good or service. ${ }^{90}$ The court thus ignored the role of the bidders, who were engaged in a quintessential

84. 15 U.S.C. $\$ \S 78 \mathrm{~m}$ (d)-(e), $78 \mathrm{n}$ (d)-(f) (1988).

85. Smolowe v. Delendo Corp., 136 F.2d 231, 240 (2d Cir.) ("That transactions on national security exchanges have taken on an interstate character, justifying regulation under the commerce clause, is now beyond doubt."), cert. denied, 320 U.S. 751 (1943); Wright v. SEC, 112 F.2d 89, 94 (2d Cir. 1940) (holding that the Securities Exchange Act of 1934 was a valid regulation of interstate commerce, as opposed to an invalid regulation of intrastate commerce); Oklahoma-Texas Trust v. SEC, 100 F.2d 888, 890-91 (10th Cir. 1939) ("The mails and the facilities of interstate commerce are commonly used to effectuate [thel sale and transfer [of securities] and we have no doubt that they should be regarded as subjects of interstate commerce and transportation."); Annotation, Federal Securities Acts, 85 LAw. ED. 506, 509-11, 543-44 (1941); see also Northern Sec. Co. v. United States, 193 U.S. 197, 331 (1904) ("Congress has the power to establish rules by which interstate and international commerce shall be governed, and, by the Anti-Trust Act, has prescribed the rule of free competition among those engaged in such commerce."); $c f$. CTS Corp. v. Dynamics Corp. of Am., 481 U.S. 69, 87-88 (1987) (assumption that contests for corporate control are in interstate commerce is implicit in Court's dormant commerce clause analysis); Wilko v. Swan, 346 U.S. 427, 430 (1953) (margin agreements are within interstate commerce), overruled on other grounds, Rodriguez De Quijas v. Shearson/American Express, 109 S. Ct. 1917 (1989); Electric Bond \& Share Co. v. SEC, 303 U.S. 419, 440-43 (1938) (interstate securities transactions of utility holding company are interstate commerce and within scope of Public Utility Act of 1935).

86. L. Sullivan, supra note $42, \S 233$, at 709 .

87. Flood v. Kuhn, 407 U.S. 258 (1972).

88. 310 U.S. 469, 497-98 (1940) (citing United States v. Addyston Pipe \& Steel Co., 85 F. 271

(6th Cir. 1898)), modified, 175 U.S. 211 (1899)).

89. See, e.g., United States v. Socony-Vacuum Oil Co., 310 U.S. 150, 223-24 (1940).

90. Kalmanovitz v. G. Heileman Brewing Co., 769 F.2d 152, 156-57 (3d Cir. 1985). 
business transaction. But the Sherman Act reaches price fixing whether by sellers or by buyers. ${ }^{91}$

Moreover, the court's alternative argument that a share of stock of a company is neither a good nor a service cannot support the rest of its argument. First, the distinction is formalistic and metaphysical. The court offers no definition or principle by which one can determine whether something is a good or service. In essence, it says that a share of stock does not smell like a "good or service," so therefore it must not be one, even though it may be bought and sold in the same manner as any other commodity. ${ }^{92}$ Those in the business of selling shares of stock seem to have a different sense of smell: Brokerage houses refer to shares of stock as "products" and "commodities."93

But even more importantly, section 1 of the Sherman Act is not itself phrased in terms of "goods and services." The court derived that limitation only from an incorrect reading of Apex Hosiery, which at most limits the Sherman Act to commercial activities as distinguished from political or labor activities. Thus Apex Hosiery provides no support for the court's attempt to carve out an ad hoc exemption within what is indisputably the commercial sector. ${ }^{94}$ There is, therefore, no basis for the court's argument that there is some anomalous region of commerce that somehow does not involve eitlier "goods or services," and that, as a result, is deprived of the protections of section 1 of the Sherman Act. ${ }^{95}$

91. Mandeville Island Farms, Inc. v. American Crystal Sugar Co., 334 U.S. 219, 235-36 (1948) (conspiracy among buyers of sugar beets found to constitute illegal price fixing); American Tobacco v. United States, 328 U.S. 781 (1946) (purchasers of leaf tobacco found to be engaged in illegal price fixing conspiracy); Swift \& Co. v. United States, 196 U.S. 375 (1905) (illegal price fixing conspiracy found among buyers of livestock); Vogel v. American Soc'y of Appraisers, 744 F.2d 598, 601 (7th Cir. 1984) (Posner, J.) (buyer cartels to force the price down are illegal per se).

92. The Tenth Circuit's analysis, almost fifty years earlier, is far more practical:

While securities are mere evidences of obligations to pay money or of rights to participate in earnings and distribution of corporate, trust, and other property and are mere choses in action, nevertheless in modern commercial intercourse they are sold, purchased, delivered, and dealt with the same as tangible commodities and other ordinary articles of commerce.

Oklahoma-Texas Trust v. SEC, 100 F.2d 888, 890 (10th Cir. 1939); see also Northern Sec. Co. v. United States, 193 U.S. 197 (1904) (holding that the formation of a trust holding shares of competing railroads violated sections 1 and 2 of the Sherman Act).

93. See, e.g., Wayne, Giving Birth to 'Unbundled'Stock, N.Y. Times, Dec. 18, 1988, at F5, col. 1 (reporting on the development of a new sort of equity security by two members of Shearson Lehman Hutton's "new product" department); see also CTS Corp. v. Dynamics Corp. of Am., 481 U.S. 69, 94 (1987) (referring to securities and corporate control as "commodities").

94. The court's strained construction of the "trade or commerce" language of section 1 is also in tension with the traditional interpretation of section 4 of the Clayton Act. Courts have long interpreted section 4 of the Clayton Act as providing a private cause of action to all who have been injured by violations of the antitrust laws, not just violations significantly affecting business competition. Reiter v. Sonotone Corp., 442 U.S. 330, 339 (1979); Brunswick Corp. v. Pueblo BowlO-Mat, Inc., 429 U.S. 477,486 n.10 (1977).

95. Although the court's reasoning in Kalmanovitz does not withstand scrutiny, the result may have been correct. What was problematic about Kalmanovitz was the prospect that Kalmanovitz, the unsuccessful bidder, could don the mantle of an injured shareholder by virtue of his 20 shares, 


\section{B. Preemption/Implied Immunity Under the Williams Act}

The second argument relied on by the court in Kalmanovitz is that federal securities laws preempt the application of the antitrust laws to the market for corporate control. But neitler the relevant statutory language, legislative history, nor judicial interpretation provides any support for the argument that the Williams Act, or any other federal securities regulation, displaces the antitrust protections in the market for corporate control.

\section{The Williams Act and the Sherman Act Do Not Impose Inconsistent Requirements on Bidders}

Neither the Williams Act $^{96}$ nor any other provision of the securities acts contains any express exemption from the antitrust laws. Therefore, any preeunption of the antitrust laws effected by those statutes "must be discerned as a inatter of implication." Out of respect for the central role that the antitrust laws play in the regulation of the economy, liow-

and charge his erstwhile partner and adversary with price fixing. This prospect is even more troubling when one considers that Jacobs had anticipated-and told Kalmanovitz-that he might drop out of the bidding if it got too rich or if it looked as if he might lose. Kalmanovitz v. G. Heileman Brewing Co., 769 F.2d 152, 154 (3d Cir. 1985).

It is hard to sec what harm the arrangement between Jacobs and Heileman caused Kalmanovitz. He continued to bid, and the shareholders, faced with a choice between the two bids, tendered into the Heileman offer. Id. at 154-55. Although his bid was higher than Heileman's, the Heileman bid closed earlier and was supported by incumbent management. Id. The shareholders presumably decided that the Heileman bid was more likely to prevail, and tendered in order to receive at least a share of the premium over the previous market price.

Thus an appropriate basis for the court's decision would have been that Kalmanovitz lacked standing to challenge the alleged violations of the Sherman Act. As the losing bidder, Kalmanovitz did not suffer "antitrust injury," that is, he was not injured by virtue of any competition displaced or destroyed by the claimed agreement between the Jacobs group and Heileman. See Brunswick Corp., 429 U.S. at 489 . In fact, Kalmanovitz benefited because Heileman's lower price made his competing offer more attractive than it otherwise would have been. Whether the arrangement between Jacobs and Heileman should properly have been construed as an agreement to stop bidding, Kalmanovitz, as a competing bidder, was the wrong party to raise the challenge: It should have been raised by a shareholder. Kalmanovitz, though nominally a shareholder by virtue of his 20 shares, was predominantly a competing bidder. As such, the court could have found that his nominal shareholdings, when compared to his very great financial stake in his competing bid, were insufficient to give him standing as a shareholder, as the court held with regard to Kalmanovitz's claims under section 14(e) of the Williams Act, 15 U.S.C. $\$ 78 \mathrm{n}(\mathrm{e})$ (1988).

Such an approach makes even more sense in the context of the antitrust claim than in the section 14(e) context. While in the antitrust context, the disappointed bidder may, in fact, have benefited from the violation, in the section 14(e) context, material omissions or misrepresentations in the tender offer materials filed by a bidder disadvantage competitors. To the extent that shareholders are misled, they cannot fairly choose between the competing bids and thus may tender to the competing bidder even though the disappointed bidder's offer would have been more attractive had appropriate disclosures been made. Piper v. Chris-Craft Indus., 430 U.S. 1, 62, 68-69 (1977) (Stevens, J., dissenting).

96. 15 U.S.C. $\$ \S 78 \mathrm{~m}(\mathrm{~d})-(\mathrm{e}), 78 \mathrm{n}$ (d)-(f) (1988).

97. Silver v. New York Stock Exchange, 373 U.S. 341, 357 (1963). 
ever, "[i]mplied antitrust immunity is not favored, and can be justified only by a convincing showing of clear repugnancy between the antitrust laws and the regnlatory systein."98 In particular, where the securities acts are involved, "[r]epeal is to be regarded as implied only if necessary to make the Securities Exchange Act work, and even then only to the minimum extent necessary." 99

The Williams Act imposes requirements in two basic areas. First, it requires disclosure of information regarding a tender offer, the tender offeror, and the purposes of the purchase. ${ }^{100}$ Second, the Act establishes procedural rules governing tender offers, including withdrawal rights, ${ }^{101}$ tender periods, ${ }^{102}$ proration, ${ }^{103}$ and the "best price" rule. ${ }^{104}$ None of the duties imposed by these rules would conflict witl the restrictions on bidding agreements potentially imposed by the Slierman Act.

The court in Kalmanovitz rejected this notion, arguing that the Slierman Act cannot apply to contests for corporate control, because Congress explicitly contemplated that tender offers might be made by a group. ${ }^{105}$ According to the court, applying the antitrust laws would render illegal a species of tender offer expressly recognized by Congress. ${ }^{106}$ In addition, by requiring that the lighest price offered be paid to all those who tender, Congress necessarily approved of offerors agreeing to fix the offering price. ${ }^{107}$ Thus, the court concluded, "had we determined that the Sherman Act was applicable, we miglit have been

98. United States v. National Ass'n of Sec. Dealers, 422 U.S. 694, 719-20 (1975); accord National Gerimedical Hosp. \& Gerontology Center v. Blue Cross, 452 U.S. 378, 388-89 (1981) ("Even when an industry is regulated substantially, this does not necessarily evidence an intent to repeal the antitrust laws with respect to every action taken within the industry."); Gordon v. New York Stock Exchange, 422 U.S. 659, 682 (1975) ("Repeal of the antitrust laws by implication is not favored and not casually to be allowed."); Otter Tail Power Co. v. United States, 410 U.S. 366, 37275 (1973) (Where agreements "are governed in the first instance by business judgment and not regulatory coercion, courts must be hesitant to conclude that Congress intended to override the fundamental national policies embodied in the antitrust laws."); United States v. Philadelphia Nat'l Bank, 374 U.S. 321, 350-51 (1963) ("Repeals of the antitrust laws by implication from a regulatory statute are strongly disfavored . ..."); United States v. Radio Corp. of Am., 358 U.S. 334, 346, 35051 (1959) (holding that the Communications Act of 1934 did not give the FCC power to decide antitrust issues as such and therefore could not block antitrust enforcement in the federal courts).

99. Silver, 373 U.S. at 357.

100. 15 U.S.C. $\S 78 \mathrm{n}(\mathrm{d})$ (1988); see also CTS Corp. v. Dynamics Corp. of Am., 481 U.S. 69, 79 80 (1987).

101. 15 U.S.C. $\S 78 \mathrm{n}(\mathrm{d})(1)$ (1988); 17 C.F.R. $\S \S 240.13 \mathrm{~d}-1,240.14 \mathrm{~d}-3$ (1989).

102. 17 C.F.R. $\$ 240.14 \mathrm{e}-1$ (a) (1989).

103. 15 U.S.C. $\S 78 \mathrm{n}(\mathrm{d})(6)$ (1988); 17 C.F.R. $\S 240.14 \mathrm{~d}-8$ (1989).

104. 15 U.S.C. $\$ 78 \mathrm{n}(\mathrm{d})(7)(1988)$.

105. Kalmanovitz v. G. Heileman Brewing Co., 769 F.2d 152, 158 (3d Cir. 1985) ("The tender offer normally consists of a bid by an individual or group to buy shares of a company-usually at a price above the current market price.") (citing H.R. REP. No. 1711, 90th Cong., 2d Sess. (1968)).

106. Id.

107. Id. 
constrained to hold the antitrust laws preempted in this context."108

This argument, however, is unpersuasive, because the plaintiffs in Kalmanovitz were not claiming that section 1 of the Sherman Act prohibits any bidding by groups, or requires that only individuals or corporations make tender offers, but, rather, that it bars competing bidders from agreeing to stop bidding. ${ }^{109}$ The difference between these two claims is fundamental to antitrust law. Section 1 jurisprudence has traditionally distinguished between naked restraints of trade, which are per se illegal, and restraints of trade that are ancillary to legitimate purposes, which are subject to the rule of reason under which the procompetitive effects are balanced against the anticompetitive effects. ${ }^{110}$ For example, an agreement ainong a group of independent law firms on the ininimum fees that they will charge their clients would clearly violate section $1 .^{111}$ A group of independent lawyers, however, may undoubtedly band together to form a partnership and, as part of their joint enterprise, agree on what fees they will charge. ${ }^{12}$ The difference is that the integration attendant on the formation of a partnership has procompetitive consequences that outweigh the accoinpanying restraints on trade. ${ }^{113}$ A naked agreement on price, on the other hand, has no procompetitive effects and is therefore per se illegal.

One can draw a similar distinction in the tender offer context. Allowing individuals to band together to make tender offers may be procompetitive: It may permit some bidders to enter the bidding, or create new bidders for larger targets, thereby increasing the competition in the market for corporate control. It does not necessarily follow, however, that competing bidders should be permitted to make agreements among themselves to displace the competitive determination of the price for control of a coinpany. ${ }^{114}$

\section{Legislative History of the Williams Act}

Nothing in the legislative history of the Williams Act indicates that Congress intended it to preempt the antitrust laws. Congress intended the Williams Act to protect shareholders caught in the midst of a battle for corporate control by filling a gap in the existing disclosure

108. Id.

109. Id. at 154-55.

110. R. BoRK, supra note 14 , at $18-19,263-80$; L. Sullivan, supra note 42 , at $\$ \S 71,76-77$.

111. See Goldfarb v. Virginia State Bar, 421 U.S. 773 (1975) (holding that a minimum fee schedule, as published by a County Bar Association and enforced by the State Bar, violates section 1 of the Sherman Act).

112. United States v. Addyston Pipe \& Steel Co., 85 F. 271, 280-81 (6th Cir. 1898), modified, 175 U.S. 211 (1899).

113. R. BORK, supra note 14, at 265 .

114. In Part III, infra, text accompanying notes 168-281, I expand this analysis and provide a more general framework for analyzing agreements within the market for control. 
requirements. ${ }^{115}$ The Senate version of the bill was purely a disclosure statute, essentially imposing the same obligations of disclosure of material facts on tender offers and corporate repurchases that already applied to exchange offers and proxy solicitations. ${ }^{116}$ The House Report manifested a similar intent in identical language as it sought "to require full and fair disclosure for the benefit of investors while at the same time providing the offeror and management equal opportunity to fairly present their case." 117

Thus neither the House report, the Senate report, nor the language of the statute itself indicates any intention to displace the antitrust laws in the context of battles for corporate control. In fact, the underlying assumption seems to have been that the disclosure requirements would facihtate a more intelligent exercise of shareholder choice within the competitive battle for control. ${ }^{18}$

\section{Judicial Interpretation of the Scope of the Williams Act}

The Supreme Court has written four principal opinions interpreting the purposes of the Williams Act: Rondeau v. Mosinee Paper Corp., ${ }^{119}$ Piper v. Chris-Craft Industries, ${ }^{120}$ Schreiber v. Burlington Northern, Inc., ${ }^{121}$ and CTS Corp. v. Dynamics Corp. of America. ${ }^{122}$ In each case, the Court interpreted the Williams Act as a provision of limited scope, designed to ensure that target shareholders have enough time and information to make a rational decision. Nothing in any of these opinions

115. S. REP. No. 550, 90th Cong., 1st Sess. 1-4 (1967); H.R. REP. No. 1711, 90th Cong., 2d Sess. 2-5 (1968); 113 CoNG. Rec. 24,664-66 (1967). See generally Johnson \& Millon, Misreading the Williams Act, 87 Mich. L. REV. 1862 (1989).

116. S. REP., supra note 115 , at 4 .

117. H.R. REP., supra note 115, at 4; see also S. REP., supra note 115 , at 3 .

118. During consideration of the proposal on the Senate floor, Senator Javits asked Senator Williams the following question:

There is no intendment in the measure, or in the fact that the measure is offered, to in any way condemn the practice of making tenders, is there? Sometimes stockholders do very well because of tenders, especially competitive tenders.

Senator Williams responded:

There is no intention in any way to prohibit tender offers. As a matter of fact, I think it might encourage them. Through this legislation people will have more information, and will be able to intelligently decide whether to accept a tender offer and sell their shares to a group which may wish to obtain a controlling interest.

Subsequently, Senator Javits continued:

[W]ith those assurances, which I think are important, I shall not stand in the way of passage of this bill. ... [T] representation and adequate information on the part of the stockholder, who could conceivably be imposed upon, without denying him the opportunities which result from the competitive bidding for a block of stock of a given company.

113 Cong. Rec. 24,665-66 (1967) (emphasis added).

119. 422 U.S. 49 (1975).

120. 430 U.S. 1 (1977).

121. 472 U.S. 1 (1985).

122. 481 U.S. 69 (1987). 
supports the suggestion that Congress intended the Williams Act to exempt control transactions from the antitrust laws.

In Rondeau v. Mosinee Paper Corp., ${ }^{123}$ the Court emphasized that the purpose of the Williams Act is to provide adequate information about the bidder to public shareholders confronted with a tender offer for their stock. In Piper v. Chris-Craft Industries, ${ }^{124}$ the Court again gave a restrictive reading to the aims of the Williams Act. There it held that the purpose of the Williains Act is simply to protect target company stockholders. In Schreiber v. Burlington Northern, Inc., ${ }^{125}$ the Court held that the misrepresentation or nondisclosure of material facts is a necessary element of a violation of section 14(e) of the Williams Act. ${ }^{126}$ The Court's narrow interpretation of 14(e), identical to its readimg of Rule $10 \mathrm{~b}-5,{ }^{127}$ indicates the limited scope of the Willians Act. The logic of the Court's argument in Schreiber depends squarely upon the existence of a competitive market for control: Full information will tend to make a market perform more competitively. As the Court stated, "[t]he expressed legislative intent was to preserve a neutral setting in which the contenders could fully present their arguments." 128

In CTS Corp. v. Dynamics Corp. of America, ${ }^{129}$ the Court considered the constitutionality of Indiana's takeover statute. ${ }^{130}$ The statute required, in effect, that, prior to acceptance, a tender offer be approved by a majority of the preexisting shareholders. ${ }^{131}$ The Supreme Court held that because entities could comply with both the Williams Act and the Indiana Act, the state statute would be preempted "only if it frustrated the purposes of the federal law." ${ }^{132}$ The Court then held that the

123. 422 U.S. 49 (1975). In Rondeau, the plaintiff corporation brought an action for injunctive relief against one of its shareholders. The latter had acquired more than $5 \%$ of the corporation's shares without filing a Schedule 13D disclosure with the corporation and the SEC within 10 days of acquisition, as required by section 13(d) of the Williams Act, 15 U.S.C. $\$ 78 \mathrm{~m}$ (d) (1988). The corporation sought to enjoin the shareholder from voting or pledging his shares, from acquiring any additional shares, and from retaining the stock he already held. The Court held that where the error was unintentional and the shareholder had not attempted to obtain control of the corporation, the requirements for an injunction have not been satisfied.

124. 430 U.S. 1 (1977). In Piper, a losing tender offeror sued management and the successful white knight bidder for violations of section 14(e), the provision of the Williams Act requiring disclosure of all material facts, 15 U.S.C. $\$ 78 \mathrm{n}(\mathrm{e})$ (1988).

125. 472 U.S. 1 (1985).

126. 15 U.S.C. $\S 78 n(e)(1988)$.

127. Santa Fe Indus. v. Green, 430 U.S. $462,473-74$ (1977).

128. Scheiber, 472 U.S. at 9.

129. 481 U.S. 69 (1987).

130. CTS involved an Indiana statute applying to Indiana corporations. The statute required that in certain control-shifting transactions, the acquired shares would not receive voting rights unless a majority of all preexisting disinterested shareholders acquiesced. Id. at 72-75.

131. Id. at 73-74. Such a statute arguably provides one solution to the collective choice dilemma facing dispersed shareholders of a publicly held corporation.

132. Id. at 79 . 
purpose of the Williams Act is to protect investors, and that the Indiana Act, by allowing target shareholders to vote as a group, actually furthers the purposes of the Williams Act by protecting shareholders from the coercive aspects of some tender offers. ${ }^{133}$ Again, as in the other Williams Act cases, the Court seemed to assume both that the market for corporate control functions competitively, and that it would continue to do so. Far from finding that the Williains Act provides comprehensive regulation of the market for corporate control, the Supreme Court has consistently confirmed the Act's relatively limited reach and assumed the continued competitiveness of the market for corporate control.

More than any other case, CTS makes clear that federal regulation of the market for corporate control leaves substantial room for complementary and supplementary regulation. In CTS, the complementary regulation derived froin the state, but the argunent applies with even greater force to federal regulation. Unhike state corporate law, federal regulation is exphcitly national in scope and, accordingly, does not implicate the commerce or supremacy clauses. In short, if the Williams Act does not preempt state takeover laws that have a much more substantial effect on the market for control than the antitrust laws do, ${ }^{134}$ then it cannot preempt or impliedly repeal the antitrust laws. ${ }^{135}$

\section{The SEC and Bidding Agreements}

Leaving the preemption issue to one side, securities lawyers may still have an intuitive feeling that, if any entity should regulate bidding agreements, it should be the SEC and not the antitrust laws. ${ }^{136}$ The Commission, however, does not regulate private bidding agreements among bidders in contests for corporate control. No provisions of the securities laws specifically address such agreements, and no regulations have been promulgated or even proposed. ${ }^{137}$ As the law currently

133. Id. at 81-84.

134. See CTS Corp. v. Dynamics Corp. of Am., 481 U.S. 69 (1987); BNS, Inc. v. Koppers Co., 683 F. Supp. 458, 466-72 (D. Del. 1988) (promanagement Delaware antitakeover legislation not preempted by the Williams Act).

135. See Cantor v. Detroit Edison Co., 428 U.S. 579, 596 n.36 (1976).

136. See, e.g., Franklin, Cooperation or Collusion?: States Testing New Antitrust Theory on Stevens Deal, N.Y.L.J., Apr. 28, 1988, at 5, col. 2 ("[M]ost lawyers would probably view [bid rigging] as a manipulative practice to be addressed under the securities laws.").

137. Tender offer bidding agreements are not the sort of transactions that are regulated as "manipulation" under sections 9 and 10 of the Securities Exchange Act, 15 U.S.C. $\S \S 78 i, 78 j$ (1988), and Rules 10b-5, 10b-6, 10b-7 and 10b-18, 17 C.F.R. $\S \S 240.10 b-5,240.10 b-6,240.10 b-7,240.10 b-18$ (1989). As the Supreme Court has held, the term "manipulation" "refers generally to practiees, such as wash sales, matched orders, or rigged prices, that are intended to mislead investors by artificially affecting market activity." Santa Fe Indus., Inc. v. Green, 430 U.S. 462, 477 (1976). Sce, for example, seetion 9(a)(1) of the Securities Exchange Act, 15 U.S.C. § 78i(a)(1) (prohibiting certain transactions "for the purpose of creating a false or misleading appearance of active trading ... or a false or misleading appearance with respect to the market for any such security"), and 
stands, so long as the bidders fully disclose their bidding agreement, their arrangements are not "fraudulent, deceptive or manipulative acts" within the meaning of section 14(e) because they involve no misrepresentation or nondisclosure. ${ }^{138}$

The more interesting question is whether the Commission would have the power to prohibit bidding agreements, were it inclimed to do so. Certainly the Williams Act is somewhat more than a disclosure statute. For example, in addition to requiring disclosure, the Williams Act also provides for withdrawal rights, ${ }^{139}$ proration of shares tendered if the offer is oversubscribed, ${ }^{140}$ and "best price" protection. ${ }^{141}$ While the withdrawal rights may be logically related to the disclosure requirements (one must have the right to withdraw after considering the various disclosures made), neither the proration provision nor the best price protection relates to the disclosure requirements in any obvious way. Rather, such provisions are in the nature of ground rules estabhishing "fair and equal treatment" of target shareholders. ${ }^{142}$.The interesting issue, then, is whether the Commission could prohibit bidding agreements on the grounds that such agreements deprive target shareholders of "fair and equal treatment."

A related question arose with regard to the Commission's "All Holders Rule." 143 In Unocal Corp. v. Mesa Petroleum Co., ${ }^{144}$ the Delaware Supreme Court held that Unocal could exclude Mesa (a corporation controlled by $\mathrm{T}$. Boone Pickens), which had earher made a bid for the company, from a self tender at a substantial premium above market price. In response to that decision, the Commission promulgated the "All-Holders Rule," requiring that "a bidder making a tender offer ...

section 9(a)(2) of the Securities Exchange Act, 15 U.S.C. § 78i(a)(2) (prohibiting transactions "creating actual or apparent active trading in such security or raising or depressing the price of such security, for the purpose of inducing the purchase or sale of such security by others"). Tender offer bidding agrecments are not "manipulation" under sections 9 or 10 because they do not involve any attempt to induce purchases or sales based on the false or misleading appearance of active trading.

Indeed, any argument that fully disclosed tender offer bidding agreements constitute manipulation under sections 9 or 10(b) would fail for the same reasons that the claim in Sante Fe failed. In Sante $\mathrm{Fe}$, the plaintiffs argued that a short form merger for inadequate consideration constituted a manipulative practice under section $10(\mathrm{~b})$ and rule 10b-5. The Court rejected that claim because, first, there were no omissions or misstatements accompanying the notice of inerger (and thus the merger was not "deceptive") and, second, a merger for inadequate consideration is not within the ineaning of the term "manipulative" as used in the Securities Exchange Act (and thus the merger was not "manipulative"). Santa $F e, 430$ U.S. at 474-77. That analysis applies with equal strength to fully disclosed bidding agreements.

138. Schreiber v. Burlington N., Inc., 472 U.S. 1, 12 (1985).

139. 15 U.S.C. $\$ 78 n$ (d)(5) (1988); 17 C.F.R. § $240.14 d-7$ (1989).

140. 15 U.S.C. $\$ 78$ n(d)(6) (1988); 17 C.F.R. § 240.14d-8 (1989).

141. 15 U.S.C. $\S 78 n(d)(7)(1988)$.

142. Polaroid Corp. v. Disney, 862 F.2d 987, 995 (3d Cir. 1988).

143. 17 C.F.R. $\S 240.14 d-10$ (1989).

144. 493 A.2d 946 (Del. 1985). 
extend the offer to all security holders who own shares of the class of securities subject to the offer."145 The Commission asserted that the rule was a "necessary and appropriate" means of implementing the twin aims of the Williams Act. According to the Commission, the Act aimed "(1) to promote investor protection by requiring full and fair disclosure in connection with cash tender offers, and (2) to eliminate discriminatory treatment among security holders who may desire to tender their shares." 146 The Commission articulated two justifications for the new rule. First, it was necessary to ensure nondiscriminatory treatment of shareholders. Second, the all-holders requirement would "realize the disclosure purposes of the Williams Act by ensuring that all members of the class subject to the tender offer receive information necessary to make an informed decision regarding the merits of the tender offer."147 Because the disclosure justification for the All-Holders Rule is facially incoherent, ${ }^{148}$ the Commission's actions must rise or fall with the "nondiscriminatory" justification.

A substantial majority of those who submitted comment letters opposed the all-holders requirement, primarily on the grounds that the Commission lacked authority to promulgate the rule. ${ }^{149}$ The only federal court that had previously considered the question had suggested that such a rule would probably exceed the scope of the Commission's authority. ${ }^{150}$ Nevertheless, the only federal court to address the validity of the All-Holders Rule simce its promulgation has found the rule to be a legitiinate exercise of the Commission's authority under the Williams Act to promulgate rules that "attempt to ensure that all holders of a class of securities subject to a tender offer receive fair and equal treatment."151

The question whether the Commission would have the authority to issue a rule prohibiting bidding agreements among competing bidders pushes the inquiry one step further. The All-Holders Rule and the proration and best price provisions of the Williams Act protect shareholders from unequal or discriminatory treatment. Bidding agreements, however, do not subject shareholders to unequal treatment. Each shareholder is in the same boat: The bidders' agreement effectively caps the

145. See Amendments to Tender Offer Rules: All-Holders and Best Price, Exchange Act Release Nos. 33-6653, 34-23421, 51 Fed. Reg. 25,873, 25,874 (1986) (codified as amended at 17 C.F.R. § 240.14d-10(a)(1) (1989)).

146. 51 Fed. Reg. at 25,875 .

147. Id.

148. Discriminatory share repurchases prevent neither included nor excluded shareholders from receiving the information necessary to make an informed decision. They simply preclude one group of shareholders from receiving the tender consideration.

149. 51 Fed. Reg. at 25,874 .

150. Unocal Corp. v. Pickens, 608 F. Supp. 1081, 1082-83 (C.D. Cal. 1985).

151. Polaroid Corp. v. Disney, 862 F.2d 987, 995 (3d Cir. 1988). 
share price. ${ }^{152}$ The question whether the commission can prohibit bidding agreements thus goes beyond the question whether it could promulgate the All-Holders Rule.

If the Commission has the power to prohibit bidding agreements, then that power must spring from some authority to prohibit "unfair but non-discriminatory" behavior. But there exists no obvious source for that authority. The Supreme Court has interpreted the Williams Act as not imposing general principles of "fairness" absent evidence of discriminatory treatment. ${ }^{153}$ Moreover, such authority would seem to be openended: How would one distinguish between bidding agreements, asset lock-ups, or poison pills on fairness grounds? Each is arguably unfair, but nondiscriminatory, to the target shareholders. The better view therefore seems to be that the Commission would not-and should not-have authority to prohibit bidding agreements.

\section{The Fit with Delaware Law}

As noted earlier, the Williams Act implicitly assumes that the market for corporate control is a competitive one. ${ }^{154}$ Applying antitrust principles to the market thus protects federal regulations by supporting its basic premises. The same can be said for the relationship between antitrust and state corporate law. An analysis of Delaware law, the most important body of state corporate law, indicates that protecting competition in the market for corporate control is consistent with and seems to support the principles announced in the Delaware cases governing contests for control. Delaware law, like federal law, seems to rely, at least partially, on the continued competitiveness of the market for corporate control.

The Delaware cases addressing contests for corporate control outline four important functions that auctions can serve. First, auctions may maximize shareholders' returns. ${ }^{15 s}$ As the Delaware Supreme Court stated in Revlon, Inc. v. MacAndrews \& Forbes Holdings, Inc., 156 "[m]arket forces must be allowed to operate freely to bring the target shareholders the best price available for their equity."157 Second,

152. Even the shares held by bidders are subject to the price cap. In the typical takeover, all of the existing shares are bought by the acquisition shell, either in the tender offer or in the subsequent second-stage merger.

153. Schreiber v. Burlington N., Inc., 472 U.S. 1, 9 n.8 (1985) (Williams Act disclosure requirements do not invite courts to oversee the substantive fairness of tender offers).

154. See supra text accompanying notes 119-35.

155. See, e.g., Mills Acquisition Co. v. Macmillan, Inc., 559 A.2d 1261 (Del. 1989); Revlon, Inc. v. MacAndrews \& Forbes Holdings, Inc., 506 A.2d 173 (Del. 1986); In re Holly Farms Corp. Shareholders Litig., 1989 Fed. Sec. L. Rep. (CCH) I 94,181 (Del. Ch. 1988).

156. 506 A.2d 173 (Del. 1986).

157. Id. at 184 . 
auctions provide an effective, and sometimes the most effective means by which the target board can inform itself as to the value of the target company in a change of control. ${ }^{158}$ Third, a market test may establish or confirm that the price offered is fair or adequate. ${ }^{159}$ Fourth, because competition among bidders or between bidders and incumbent management may benefit target shareholders-thus mitigating the "omnipresent specter that a board may be acting primarily in its own interest, rather than those of the corporation and its shareholders"160_-shareholders must be allowed to choose between competing, noncoercive offers or restructuring proposals for the target company. ${ }^{161}$

Thus, in recognition of the importance of auctions for control to target companies and their shareholders, the Delaware courts have granted target boards considerable leeway in facilitating such competition. Although the current state of the law is unsettled, boards apparently may agree to asset lock-ups, break-up fees, and topping fees in order to entice potential bidders into bidding, so long as these tactics are not "show stoppers."162 Likewise, a board may adopt "poison pill" rights plans to gain time to solicit competing bids or prepare an alternative restructuring plan to present to the shareholders. ${ }^{163}$

Each of the four roles played by auctions require or assume, to varying degrees, that the market for control is reasonably competitive.

158. Barkan v. Amsted Indus., Inc., 567 A.2d 1279 1286-87 (Del. 1989); Smith v. Van Gorkom, 488 A.2d 858, 878 (Del. 1985); In re RJR Nabisco, Inc. Shareholders Litig., 1989 Fed. Sec. L. Rep. (CCH) I 94,194, at 91,713 (Del. Ch. 1989), appeal refused, 556 A.2d 1070 (Del. 1989); City Capital Assocs. Ltd. Partnership v. Interco, Inc., 551 A.2d 787, 803 (Del. Ch. 1988); In re Fort Howard Corp. Shareholders Litig., No. 9991 (Del. Ch. Aug. 8, 1988) (LEXIS, States library, Del. file) (merger agreement which provided for market test gave the board an informed, dependable basis to accept tender), aff'd, No. 332 (Del. Aug. 16, 1988) (LEXIS, States library, Del. file).

159. Grand Metro., PLC v. Pillsbury Co., 558 A.2d 1049, 1056-57 (Del. Ch. 1988); In re Fort Howard Corp. Shareholders Litig., No. 9991 (Del. Ch. Aug. 8, 1988) (LEXIS, States library, Del. file), aff'd, No. 332 (Del. Aug. 16, 1988) (LEXIS, States library, Del. file).

160. Unocal, Corp. v. Mesa Petroleum Co., 493 A.2d 946, 954 (Del. 1985).

161. Grand Metro., 558 A.2d at 1060; Robert M. Bass Group, Inc. v. Evans, 552 A.2d 1227, 1243-44 (Del Ch. 1988); City Capital, 551 A.2d at 797-98; AC Acquisitions Corp. v. Anderson, Clayton \& Co., 519 A.2d 103, 113 (Del. Ch. 1986); see also Hanson Trust PLC v. ML SCM Acquisition, Inc., 781 .F.2d 264, 277-81 (2d Cir. 1986).

162. Revlon, Inc. v. MacAndrews \& Forbes Holdings, Inc., 506 A.2d 173, 183 (Del. 1986); In re J.P. Stevens \& Co. Shareholder Litig., 542 A.2d 770, 781 (Del. Ch. 1988); In re Holly Farms Corp. Shareholders Litig., 1989 Fed. Sec. L. Rep. (CCH) If 94,181, at 91,644 (Del. Ch. 1988); MAI Basic Four, Inc. v. Prime Computer, Inc., 1989 Fed. Sec. L. Rep. (CCH) 1) 94,179, at 91,634 (Del. Ch. 1988).

163. Revlon, Inc., 506 A.2d at 181-84; Moran v. Household Int'1, Inc., 500 A.2d 1346, 1351 (Del. 1985); Tate \& Lyle PLC v. Staley Continental, Inc., 1988 Fed. Sec. L. Rep. (CCH) \93,794, at 98,587 (Del. Ch. 1988); City Capital Assocs. Ltd. Partnership v. Interco, Inc., 551 A.2d 787, 798 (Del. Ch. 1988); J.P. Stevens, 542 A.2d at 781-82. It is unsettled whether a board that in good faith determines that the target company should be "managed for a long term" and not be sold or restructured, can adopt and retain a poison pill rights plan that prevents any bid from succeeding (the "just say no" defense). See TW Servs., Inc. v. SWT Acquisition Corp., 1989 Fed. Sec. L. Rep. (CCH) $\uparrow 94,334$ (Del. Ch. 1989). 
Otherwise, participants could not rely on the market for control to maximize share value, inform the board, confirm the adequacy of the price offered, or mediate the board's potential conflict of interest. For example, consider the sale of the Fort Howard paper company. ${ }^{164}$ In that case, the Delaware Court of Chancery found that a forty-three-day period during which the company had held itself open for inquiries and offers from third parties, but had received none, provided an adequate basis for the board's decision to accept the management-affiliated buyout proposal. If, however, management or its partners had agreed in advance with the most likely bidders for Fort Howard that they would not bid, the market test would have provided a substantially less persuasive basis for the board's decision.

Although Delaware law assumes a competitive market for control, it does not provide for one: Delaware neither prohibits nor regulates bidding agreements, ${ }^{165}$ nor does it have any set of regulations designed to protect the competitive processes within the market for control. ${ }^{166}$ Yet, as the Delaware Chancery Court has recognized, bidding agreements among competing bidders present a "clear and present danger" to target shareholders. ${ }^{167}$ Thus, construing the federal antitrust laws to protect the bidding process would not only be consistent with Delaware law, but it would actually support the basic foundations of the recent Delaware cases. The point is simple: Interpreting the antitrust laws to protect the integrity of the market for corporate control would provide the fundamental protections implicitly assumed by Delaware's developing jurisprudence of corporate control.

\section{E. The First Conclusion: Antitrust Should Apply}

The previous Sections demonstrate that bidding agreements threaten the fundamental distributional and allocational goals of the antitrust laws. Moreover, competition in the market for control plays an important role in corporate governance, both on a federal and state level.

The principal arguments for exempting the market for control from the antitrust laws are unpersuasive. Neither the Kalmanovitz court's

164. In re Fort Howard Corp. Shareholders Litig., No. 9991 (Del. Ch. Aug. 8, 1988) (LEXIS, States library, Del. file), aff'd, No. 332 (Del. Aug. 16, 1988) (LEXIS, States library, Del. file).

165. In re Sea-Land Corp. Shareholders Litig., 1988 Fed. Sec. L. Rep. (CCH) I 93,923 (Del. Ch. 1988).

166. No antitrust immunity arises under the "state action" doctrine for two reasons. First, Delaware does not have any clearly articulated and affirmatively expressed state policy to permit bidding agreements in the market for control. Second, Delaware does not actively supervise tender offer bidding agreements. Southern Motor Carriers Rate Conference, Inc. v. United States, 471 U.S. 48, 57 (1985); California Retail Liquor Dealers Ass'n v. Midcal Aluminum, Inc., 445 U.S. 97, 105 (1980).

167. In re Holly Farms Corp. Shareholders Litig., 564 A.2d 342, 349 (Del. Ch. 1989). 
linguistic argument nor any preemption argument can be defended; on the contrary, to the extent that the Williams Act is concerned with competition, it assumes that the market for control is competitive. Similarly, the more general argument that the Securities and Exchange Commission should regulate bidding agreements cannot justify exempting the market for control from the antitrust laws. The SEC does not, and, under current statutory authority, probably could not regulate bidding agreements or provide any sort of comprehensive protection of competition in the market for control. Finally, application of the antitrust laws to the market for control would not interfere with the extensive state regulation of corporations; rather, it would complement the state systems.

Consequently, the antitrust laws should apply to the market for corporate control. I now turn to the more difficult, second stage of the inquiry, namely, how the antitrust laws should be applied to the market for control.

\section{III}

TOWARDS AN ANTITRUST JURISPRUDENCE OF THE MARKET FOR CORPORATE CONTROL

Having concluded that the antitrust laws should apply to the market for corporate control, this Part examines the shape which that application should take. I sketch out a general analysis of the application of the antitrust laws to the market for corporate control, consider the appropriate scope of the per se rule and the rule of reason, and address a number of subsidiary questions. Finally, I apply the general analysis to greenmail.

\section{A. The Problem: The Variety of Agreements}

Bidding agreements among actual bidders come in a variety of forms. In the battle for J.P. Stevens, West Point-Pepperell and Odyssey Partners agreed to stop bidding against each other and divide the target. ${ }^{168}$ In the battle over Federated Department Stores, Macy's agreed to stop bidding, in return for which Campeau agreed to sell two Federated divisions to Macy's and to pay Macy's an estimated $\$ 60$ million. ${ }^{169}$ In the battles for Fruehauf, American Standard, and Pabst, the prevailing bidder paid substantial sums to the competing bidder to drop out, but did not divide the assets. ${ }^{170}$

When the analysis expands to include all agreements relating to bidding, one encounters a variety of potentially troublesome issues: What

168. See supra note 4.

169. See supra note 5 .

170. See supra note 6 (Fruehauf, American Standard) \& text accompanying notes $70-74$ (Pabst). 
about investor groups? bidders who form a joint venture before the bidding starts? acquisition partnerships formed by investment bankers and institutional investors? agreements for financing between bidders and lending institutions? How should these different sorts of agreements, which present different dangers to competition, be analyzed? An antitrust jurisprudence of the inarket for corporate control must address these questions.

\section{B. Preliminary Considerations}

Section 1 of the Sherman Act provides that "[e]very contract, combination ... ., or conspiracy, in restraint of trade or coinmerce . . is declared to be illegal."171 It was recognized from the start that section 1 could not really mean every contract, combination, or conspiracy, ${ }^{172}$ as then all contracts would be illegal because the essence of a contract is to restrain trade. ${ }^{173}$ Accordimgly, section 1 has consistently been interpreted to prohibit only those contracts, combinations, or conspiracies which unreasonably restrain trade. ${ }^{174}$ In large part, the task of section 1 jurisprudence has been to develop primciples to identify such agreements.

The fundanental approach to distinguishing between agreements that violate section 1 and those that do not is the "rule of reason." 175 In Chicago Board of Trade v. United States ${ }^{176}$ Justice Brandeis defined the standard as "whether the restraint imposed is such as inerely regulates and perhaps thereby proinotes coinpetition or whether it is such as inay suppress or even destroy competition." 177 In National Society of Professional Engineers $v$. United States ${ }^{178}$ Justice Stevens formulated the test as "whether the challenged agreement is one that promotes competition or one that suppresses competition."179

Within the general scope of the rule of reason, there are some fairly well defined subcategories, including agreennents that are per se illegal and, for lack of a better term, per se legal. The illegal per se characterization applies to agreements "which because of their pernicious effect on competition and lack of any redeeming virtue are conclusively presumed to be unreasonable and therefore illegal without elaborate inquiry as to

171. 15 U.S.C. $\$ 1$ (1988).

172. United States v. Joint Traffic Ass'n, 171 U.S. 505, 568 (1898).

173. National Soc'y of Professional Eng'rs v. United States, 435 U.S. 679, $687-88$ (1978); Chicago Bd. of Trade v. United States, 246 U.S. 231, 238 (1918).

174. Northwest Wholesale Stationers, Inc. v. Pacific Stationery \& Printing Co., 472 U.S. 284, 289-90 (1985); Professional Eng'rs, 435 U.S. at 690; Standard Oil Co. v. United States, 221 U.S. 1, 58-60 (1911).

175. Standard Oil, 221 U.S. at 58-60.

176. 246 U.S. 231 (1918).

177. Id. at 238 .

178. 435 U.S. 679 (1978).

179. Id. at 691 . 
the precise harm they have caused or the business excuse for their use." 180 Horizontal price fixing, ${ }^{181}$ bid rigging, ${ }^{182}$ and horizontal market division $^{183}$ are classic per se violations.

Agreements that pose no significant anticompetitive dangers are, for all practical purposes, per se legal. Included in this category are the vast majority of contracts, mergers within competitive markets (for example, a merger between two adjoining wheat farmers), agreements among individuals to form firms where none of the individuals is currently in the market, and so forth. ${ }^{184}$

The difficult questions under section 1 are the appropriate scope of per se rules, and how to treat arrangements that fall between the two extremes: arrangements that are not so clearly anticompetitive as to justify per se condemnation, nor so clearly harmless as to justify per se legality. This is the realm of the rule of reason. Some of the agreements

180. Northern Pac. Ry. v. United States, 356 U.S. 1, 5 (1958). Per se rules are critical because of their clarity and enforceability: They mark certain arrangements "off limits." FTC v. Superior Court Trial Lawyers Ass'n, 110 S. Ct. 768, 781-82 (1990). Per se rules apply both because of considerations of administrative convenience and because the prohibited conduct poses a threat to the free market, whether or not harm is caused in the particular instance. Id. at 779-82.

181. See, e.g., Superior Court Trial Lawyers Ass'n, $110 \mathrm{~S}$. Ct. at 779; Arizona v. Maricopa County Medical Soc'y, 457 U.S. 332, 344-48 (1982); Catalano, Inc. v. Target Sales, Inc., 446 U.S. 643, 646-47 (1980); Kiefer-Stewart Co. v. Joseph E. Seagram \& Sons, Inc., 340 U.S. 211, 213 (1951); United States v. Socony-Vacuum Oil Co., 310 U.S. 150, 212-14 (1940); United States v. Trenton Potteries Co., 273 U.S. 392, 396-98 (1927).

182. See infra notes $195-204$ and accompanying text.

183. United States v. Topco Assocs., Inc., 405 U.S. 596, $607-08$ (1972); Northern Pac. Ry., 356 U.S. at 5-6; United States v. Addyston Pipe \& Steel Co., 85 F. 271, 291-92 (6th Cir. 1898), modified, 175 U.S. 211 (1899).

184. One can also include within this category agreements in which there may be some theoretical restraint on competition, but where, because of the insignificance of the likely anticompetitive effects or the connection between the restraint and procompetitive activities, the procompetitive effects outweigh the anticompetitive consequences without any extended analysis. Such agrecments include, for example, Judge Taft's classic list of partial restraints of tradc that are generally upheld:

agreements (1) by the seller of property or business not to compete with the buyer in such a way as to derogate from the value of the property or business sold; (2) by a retiring partner not to compete with the firm; (3) by a partner pending the partnership not to do anything to interfere, by competition or otherwise, with the business of the firm; (4) by the buyer of property not to use the same in competition with the business retained by the seller; and (5) by an assistant, servant, or agent not to compete with his master or employer after the expiration of his time of service.

Addyston Pipe \& Steel, 85 F. at 281. Such agreements, Taft argued, were permissible where "ancillary to the main purpose of a lawful contract, and necessary to protect the covenantee in the enjoyment of the legitimate fruits of the contract, or to protect him from the dangers of an unjust use of those fruits by the other party." Id. at 282.

In such circumstances, one need not engage in any extended inquiry into the conditions of the industry, the market definition, or the likely procompetitive and anticompetitive effects to conclude that the agreements are permissible. Either the agreements are per se lawful, or the rule of reason can be applied in a "twinkling of the eye." P. AREEDA, THE "Rule OF REASON" IN ANTITRUST ANALYSIS: GENERAL IsSUES 37-38 (Federal Judicial Center, June 1981), quoted in NCAA v. Board of Regents, 468 U.S 85, 110 n.39 (1984). 
described above seem to fall into the per se illegal category, some into a iniddle ground, and soine into the per se legal category. Cases falling in the middle ground typically involve soine sort of partial integration ainong players, potential players, and/or non-players in the market for corporate control. These cases are often difficult because, to varying degrees, they have both procompetitive and anticompetitive effects. As discussed below, one can structure the inquiry to eliminate a large number of situations, thus focusing on the truly hard cases by ineans of several simple principles within the generally accepted frainework for analyzing joint ventures. ${ }^{185}$

\section{Joint Ventures in the Market for Corporate Control: Sorting Out the Hard Cases}

When one considers the full range of agreements ainong bidders, potential bidders, and non-bidders, the procoinpetitive and anticompetitive effects emerge in varying proportions. Consider the following general structure: $A$ and $B$ form a joint venture, $A B$ Acquisition, to acquire target corporation $T$. If neither $A$ nor $B$ would have otherwise bid for $T$, the forination of $A B$ could increase the competition for control of $T$ by creating an additional bidder. Even if $A$ and/or $B$ might have entered the bidding for $T$ on their own, their joint venture could have significant procompetitive effects. $A B$ would be a stronger, better financed, and better inforned bidder than either $A$ or $B$ would be alone. ${ }^{186}$ Moreover, $A B$ might combine the urnque skills and abilities of $A$ and $B$ in a complementary fashion, making $A B$ better able to manage $T$ than either $A$ or $B$ would be independently. ${ }^{187}$ Allowing $A$ and $B$ to form $A B$ and sinilar arrangements may also allow thein to diversify their investınents in an optimal fashion; this in turn may inake each inore willing to participate in bids for control. Finally, the formation of $A B$ inay allow for the inost efficient division of the assets of $T$.

At the same time, there may be significant anticompetitive dangers

185. See generally Brodley, Joint Ventures and Antitrust Policy, 95 HARV. L. REv. 1521 (1982) [hereinafter Brodley, Joint Ventures]; Brodley, The Legal Status of Joint Ventures Under the Antitrust Laws: A Summary Assessment, 21 ANTITRUST BULL. 453 (1976); Pitofsky, A Framework for Antitrust Analysis of Joint Ventures, 74 GEo. L.J. 1605 (1986) [hereinafter Pitofsky, Joint Ventures]; Pitofsky, Joint Ventures Under the Antitrust Laws: Some Reflections on the Significance of Penn-Olin, 82 Harv. L. Rev. 1007 (1969) [hereinafter Pitofsky, Penn-Olin].

186. Brodley, Joint Ventures, supra note 185, at 1525; Pitofsky, Joint Ventures, supra note 185, at 1606-07; see also United States v. FCC (Satellite Business Sys.), 652 F.2d 72, $96-97$ (D.C. Cir. 1980).

187. See, e.g., In re Brunswick Corp., 94 F.T.C. 1189-90, 1217-19 (1979), aff'd sub nom. Yamaha Motor Co. v. FTC, 657 F.2d 971 (8th Cir. 1981), cert. denied, 456 U.S. 915 (1982); ANTITRUST Division, U.S. Dep'T OF JUSTICE, ANTITRUST GUIDE FOR INTERNATIONAL Operations 19-20 (1977); Section of ANTitrust Law, Am. Bar Ass'N, ANTITRUst Law Developments 49-50 (2d ed. 1984); Pitofsky, Joint Ventures, supra note 185, at 1606. 
stemming from the joint venture. $A B$ may represent nothing more than an agreement eliminatimg competition between $A$ and $B$ in the contest for $T{ }^{188}$ The formation of $A B$ may discourage other potential bidders from entering the contest for control. Finally, the formation of $A B$ may dampen competition between $A$ and $B$ outside of the scope of $A B$ 's activities. $^{189}$ Different arrangements will manifest these procompetitive and anticompetitive features in differing proportions.

The possibilities present even in this relatively simple example demonstrate why the rule of reason has been notoriously difficult to apply. ${ }^{190} \mathrm{By}$ what measure does one balance procompetitive gains against anticompetitive losses? On an individual case-by-case basis the task appears difficult, if not hopeless. By providing a structure to the inquiry, however, a rough balance can be approximated. Where one is confident that the anticompetitive effects will outweigh the procompetitive effects, the illegal per se rule eliminates the need for a case-by-case balancing of competitive effects. Similarly, various limiting principles have been proposed to describe a category of legal per se cases. ${ }^{191}$ Thus many of the cases likely to arise in the context of the market for corporate control can be disposed of by means of a rule of per se illegality and a rule of per se legality.

\section{The Scope of the Per Se Rule}

Courts have traditionally deemed certain sorts of agreements to be per se illegal. ${ }^{192}$ In these agreements, the anticompetitive effects need not outweigh the procompetitive gains in all instances; rather, when the harm to the competitive process is sufficiently clear, and the procompetitive justifications are sufficiently speculative, one can dispense with an

188. See, e.g., Timken Roller Bearing Co. v. United States, 341 U.S. 593, 597-98 (1951), partially overruled on other grounds, Copperweld Corp. v. Independence Tube Corp., 467 U.S. 752 (1984); Yamaha Motor Co. v. FTC, 657 F.2d 971, 979-81 (8th Cir. 1981), cert. denied, 456 U.S. 915 (1982); Brodley, Joint Ventures, supra note 185, at 1530-32; Pitofsky, Joint Ventures, supra note 185, at 1606.

189. Brodley, Joint Ventures, supra note 185, at 1530-31; Pitofsky, Joint Ventures, supra note 185, at 1610-11. This potential dampening of competition may affect both the market for corporate control and those product markets in which $A$ and $B$ compete. If $A$ and $B$ are both players in the market for control, then their formation of $A B$ to acquire $T$ may, as a side effect, also limit thc extent to which they will compete for acquisition of Corporation $U$. Likewise, if $A$ and $B$ are competitors in some product market, say widgets, working together in the acquisition of $T$ may make them less likely to compete in the sale of widgets because they will have developed cooperative habits (and perhaps even a sense of "collective self-interest").

190. See, e.g., Northern Pac. Ry. v. United States, 356 U.S. 1, 5 (1958); Easterbrook, The Limits of Antitrust, 63 TEx. L. Rev. 1, 11-14 (1984); Posner, The Next Step in Antitrust Treatment of Restricted Distribution: Per Se Legality, 48 U. CHI. L. Rev. 6, 14-15 (1981).

191. See Easterbrook, supra note 190, at 39-40.

192. See supra text accompanying notes $180-83$. 
elaborate, costly, and often ultimately indeterminate inquiry. ${ }^{193}$ Consequently, once a practice has been determined per se illegal, the rule governing that practice need not "be rejustified for every industry that has not been subject to significant antitrust hitigation."194

\section{a. Naked Bidding Agreements Among Competitors Are Per Se Illegal}

In other contexts, bidding agreements whose purpose or effect is to eliminate coinpetition between bidders ("naked bidding agreements") have unformly been held per se illegal. Bidding agreements are simply one form of price fixing, the archetypal example of a per se violation of the Sherman Act. ${ }^{195}$ Auctions typically require that coinpetition among the bidders determine the selling price. Agreements between coinpeting bidders on what bids to submit, and on whether to bid in the first place, are one of the forms that price fixing takes in auction markets. The rule against price fixing applies regardless of who the price fixer is: Price fixing among buyers is every bit as illegal as price fixing ainong sellers. ${ }^{196}$

As a result, courts have consistently held that such agreeinents are

193. See, e.g., FTC v. Superior Court Trial Lawyers Ass'n, 110 S. Ct. 768, 779 (1990); Arizona v. Maricopa County Medical Soc'y, 457 U.S. 332, 342-44 (1982); Northern Pac. Ry., 356 U.S. at 5. The costs of a case specific inquiry include litigation expenses, see Maricopa County, 457 U.S. at 343; Northern Pac. Ry., 356 U.S. at 5, the reduced deterrence provided by vague, fact-specific standards, and the loss to society of mistakes made by judges who often lack sufficient expertise or experience to determine a practice's effects on competition, Maricopa County, 457 U.S. at 343 (citing United States v. Topco Assocs., Inc., 405 U.S. 596, 609-10 (1972)) (noting that the per se rules are motivated in part by the inability of courts generally to compare the destruction of competition in one sector of the economy with the promotion of competition in another).

194. Maricopa County, 457 U.S. at 351. Part of the rationale for per se rules is to avoid "the necessity for an incredibly complicated and prolonged economic investigation into the entire history of the industry involved, as well as related industries, in an effort to determine at large whether a particular restraint has been unreasonable-an inquiry so often wholly fruitless when undertaken." Northern Pac. Ry., 356 U.S. at 5.

195. Catalano, Inc. v. Target Sales, Inc., 446 U.S. 643,647 (1980); United States v. SoconyVacuum Oil Co., 310 U.S. 150 (1940). Commentators across the spectrum of antitrust opinion agree that such naked agreements fixing prices among competitors are and should be per se illegal. See, e.g., R. BoRK, supra note 14, at 269; R. PoSNER, supra note 14, at 39-77; L. SulLIVAN, supra note 42, § 70, at 193-94; Kauper, The Sullivan Approach to Horizontal Restraints, 75 CALIF. L. REv. 893, 894-95 (1987).

196. Mandeville Island Farms, Inc. v. American Crystal Sugar Co., 334 U.S. 219, 223-24, 235 (1948); American Tobacco Co. v. United States, 328 U.S. 781, 809 (1945); Vogel v. American Soc'y of Appraisers, 744 F.2d 598, 601 (7th Cir. 1984) (Posner, J.) ("[B]uyer cartels, the object of which is to force the prices that suppliers charge the members of the cartel below the competitive level, are illegal per se."). Just as a sellers' cartel enables the payment of monopoly prices, a buyers' cartel enables the charging of monopsony prices; and monopoly and monopsony are symmetrical distortions of competition from an economic standpoint. See Live Poultry Dealers Protective Ass'n v. United States, 4 F.2d 840, 842-43 (2d Cir. 1924) (Hand, J.) ("We should have supposed that, if one thing were definitely settled, it was that the Sherman Act forbade all agreements preventing competition in price among a group of buyers, otherwise competitive, if they are numerous enough to affect the market."); G. STIGLER, THE ThEORY OF PRICE 205-06 (3d ed. 1966); see also SoconyVacuum, 310 U.S. at 213-14. 
per se violations of the Sherman Act. Courts have found such violations in a wide variety of contexts, including bidding for construction projects, ${ }^{197}$ supply contracts, ${ }^{198}$ and the right to show films, ${ }^{199}$ and at auctions of livestock, ${ }^{200}$ tobacco, ${ }^{201}$ timber, ${ }^{202}$ used machinery, ${ }^{203}$ and antiques. ${ }^{204}$ Structurally, each bidding arrangement is the same: Agreement rather than competition among the bidders determines the price.

\section{b. The Same Rule for the Market for Control}

There is no reason to apply a different rule to naked bidding agreements in the market for control. The per se rule presumptively applies to familiar anticompetitive arrangements in new markets. ${ }^{205}$ Along with this fundamental presuinption, consider the hikely effect on competition of the paradigmatic case in the market for control in which two bidders compete for a target, and one bidder directly pays the other not to bid. ${ }^{206}$

The anticoinpetitive effect of a naked bidding agreement among actual bidders is clear: One of two bidders is lost. As discussed above, such an agreement may have substantial distributional and allocational effects. It may reduce the price paid for the target, thereby redistributing

197. See, e.g., United States v. Sargent Elec. Co., 785 F.2d 1123, 1127 (3d Cir.), cert. denied, 479 U.S. 819 (1986); United States v. W.F. Brinkley \& Son Constr. Co., 783 F.2d 1157, 1161-62 (4th Cir. 1986); United States v. Koppers Co., 652 F.2d 290, 294 (2d Cir.), cert. denied, 454 U.S. 1083 (1981); United States v. Brighton Bldg. \& Maintenance Co., 598 F.2d 1101, 1106 (7th Cir.), cert. denied, 444 U.S. 840 (1979); United States v. Flom, 558 F.2d 1179, 1183 (5th Cir. 1977); United States v. Bensinger Co., 430 F.2d 584, 589 (8th Cir. 1970); see also United States v. Dynalectric Co., 1988-2 Trade Cas. (CCH) đ 68,319 (6th Cir. 1988) (not recommended for full-text publication by the Sixth Circuit).

198. United States v. Addyston Pipe \& Steel Co., 85 F. 271 (6th Cir. 1898), modified, 175 U.S. 211 (1899).

199. United States v. Capitol Serv., Inc., 568 F. Supp. 134, 155 (E.D. Wis. 1983), aff'd, 756 F.2d 502 (7th Cir.), cert. denied sub nom. United Artists Communications, Inc. v. United States, 474 U.S. 943 (1985); General Cinema Corp. v. Buena Vista Distrib. Co., 532 F. Supp. 1244, 1279 (C.D. Cal. 1982). But see Viking Theatre Corp. v. Paramount Film Distrib. Corp., 320 F.2d 285 (3d Cir. 1963), aff'd per curiam by an equally divided court, 378 U.S. 123 (1964) (movie split agreements are not per se illegal where they include all exhibitors and seller of films is party to the agreement).

200. Swift \& Co. v. United States, 196 U.S. 375 (1905).

201. American Tobacco Co. v. United States, 328 U.S. 781 (1946).

202. United States v. Champion Int'l Corp., 557 F.2d 1270 (9th Cir. 1977).

203. United States v. Seville Indus. Mach. Corp., 696 F. Supp 986 (D.N.J. 1988).

204. See, e.g., United States v. Pook, No. $87-00274$ (E.D. Pa. Apr. 18, 1988) (LEXIS, Genfed library, Dist file), aff'd, 856 F.2d 185 (3d Cir. 1988).

205. FTC v. Superior Court Trial Lawyers Ass'n, 110 S. Ct. 768, 780-82 (1990); Arizona v. Maricopa County Medical Soc'y, 457 U.S. 332, 349-51 (1982); United States v. Socony-Vacuum Oil Co., 310 U.S. 150, 222 (1940).

206. This sort of payment occurred in the battle for control of Fruehauf between Asher Edelman and incumbent management, and in the battle for control of American Standard between Black \& Decker and Kelso. See supra note 6. Even where management is not itself a bidder, such agreements may be anticompetitive. See discussion of corporate greenmail infra notes 263-81 and accompanying text. 
wealth from target shareholders to bidders. ${ }^{207}$ It may decrease allocative efficiency by allowing a lesser valuing user to obtain control of the target's assets, and by reducing management's incentives to build up future targets. ${ }^{208}$

Two arguments can be made against applyimg the general per se rule to this situation. First, one might argue that the possibility of bemg paid off by a competing bidder will make bidding more attractive and thereby increase the number of bidders, thus making the market for control more coinpetitive. $^{209}$ But that argument would apply with equal force to bidding agreements in every market and therefore cannot justify applying a different rule to the market for control. Furthermore, the argument relies on a purely speculative procompetitive effect to justify a clear and actual restriction on competition. ${ }^{210}$ One purpose of adopting per se rules is to avoid precisely that sort of time consuming, expensive, and ultimately indeterminate imquiry. ${ }^{21}$ Absent persuasive evidence that prohibiting naked bidding agreements will in fact significantly reduce the number of bidders, a mere possibility that it will do so is insufficient to displace an existing per se rule.

Second, one might argue that naked bidding agreements are allocationally efficient and therefore should not be subject to per se condemnation. ${ }^{212}$ This argument is also implausible. In the naked bidding agreement, $A$ pays $B$ not to bid. Either $A$ is or is not the highest valuing user. If $A$ is the highest valuing user, then $A$ will win the auction without any agreement. In that case, the bidding agreement increases allocational efficiency only to the extent that it decreases transaction costs. On the other hand, if $B$ is the highest valuing user, but $A$ prevails because of the bidding agreement, then the bidding agreement decreases allocational efficiency. Moreover, the efficiency of allocating contracts or lots by means of a private agreement ainong competitors, rather than by open competition, has never been enough on its own to save such an arrangement from per se condemnation. ${ }^{213}$ Finally, one should question whether any allocational efficiency from bidding agreements could not also be accomplished by less anticompetitive means.

207. See supra note 17 and accompanying text.

208. See supra note 29 and accompanying text.

209. See supra note 21 and accompanying text. The Kalmanovitz case may have presented this situation. Had Jacobs not been permitted to reach a deal with Heileman, he might not have bid in the first place. On the other hand, he might have bid and then continued bidding with Kalmanovitz, thereby benefiting the shareholders.

210. While the existencc of an anticompetitive effect is clear, the magnitude is completely speculative.

211. Northern Pac. Ry. v. United States, 356 U.S. 1, 5 (1958).

212. See supra note 30 and accompanying text.

213. See, e.g., Addyston Pipe \& Steel Co. v. United States, 175 U.S. 211, 238 (1899); United States v. Seville Indus. Mach. Corp., 696 F. Supp 986 (D.N.J. 1988). 


\section{c. The Boundaries of the Per Se Rule}

But what about the situation in which two firms currently bidding for a target meet and say, "Look, we are each only interested in part of the target, so why don't we make one bid for the target and split its assets?"214 How does a bidding agreement accompanying a division of the target relate to the paradigm case? On the anticompetitive side, there is the same loss to competition-one bidder where there would have been two. On the procompetitive side, it inay be cheaper, easier, and inore efficient to arrange the division of assets before the gavel drops, rather than after, since each bidder is interested only in part of the prize and would sell off the unwanted part in any event. Moreover, the possibility of making such agreements may encourage some bidders to enter auctions in the first place.

Given these potential procoinpetitive effects, should the per se rule apply? Such agreements are examples of arrangenents that involve a partial integration of bidders (here the agreed division of the target's assets) and also ehminate price competition among the parties. In order for such arrangements to escape per se condeinnation, they inust generally satisfy two conditions. ${ }^{215}$ First, the elimination of price coinpetition must be necessary to the partial integration of the parties. ${ }^{216}$ Second, the elimination of price coinpetition among the parties to the agreement must not significantly reduce price coinpetition in the relevant market. ${ }^{217}$

Bidding agreeinents accompanying asset divisions satisfy neither condition. An agreement on the division of assets alone has less of an effect on price competition than a division of assets combined with an agreement not to compete. For exainple, suppose that Bidders $A$ and $B$ agree to split a company with four divisions: $K, L, M$, and $N$. $A$ says, "If I win, I'll sell you $L$ and $M$ divisions for $\$ Z$ million; if you win, you sell me $K$ and $L$ divisions for $\$ W$ million." Such an agreement still leaves open the question whether $A$ or $B$ will prevail, and at what price. If $A$ and $B$ are the only bidders, the effect of such an agreement is to cap the price of $T$ at $\$ Z+W .^{218}$ If, however, $A$ and $B$ also agree that $B$ will drop out of the bidding, $A$ may acquire $T$ for less than $\$ Z+W$, since there will be no competition from $B$ to spur the bidding upward.

More inportantly, in the typical bidding agreement with an accoinpanying division of assets, the second condition-elimination of price

214. This may have been the case, or part of the case, in the battles for J.P. Stevens and Federated Department Stores. See supra notes 4 \& 5.

215. L. Sullivan, supra note $42, \S 77$, at $206,208-10$.

216. Id.

217. Id.; see also Northwest Wholesale Stationers, Inc. v. Pacific Stationery \& Printing Co., 472 U.S. 284, 296 (1985).

218. $A$ will pay no more than its valuation of divisions $K$ and $L$, that is, $\$ W$, plus what $A$ and $B$ have agreed that $B$ will pay for the remaining divisions, namely $\$ Z$, and vice versa. 
competition among the parties to the agreement must not significantly reduce price competition in the relevant market-is frequently not satisfied. In the battle for J.P. Stevens, for exainple, when Odyssey Partners and West Point-Pepperell threw in together, they were the only bidders for Stevens. Consequently, their bidding agreement eliminated all price competition in the Stevens "market."219 Bidding agreements accompanying divisions of assets thus seem to fall within the per se rule.

This conclusion inakes sense for several reasons. First, the loss to coinpetition - one bidder where there would have been two-is clear and actual, while the coinpetitive gam-a more efficient division of the target firm-is speculative. Second, in any individual case, it would be difficult to ascertain whether the prospect of efficiently dividing the target's assets, and not of capping the amount they must pay for them, was the parties' predominant inotivation for agreeing not to bid competitively. Third, there is a substantial potential for deceptive behavior. If asset divisions are subject to a inore permissive analysis than direct payments, direct payments could be disguised as asset divisions. Finally, making all bidding agreements among competing ${ }^{220}$ bidders per se illegal sends the appropriate inessage to the marketplace. Competitors must not imterfere with the price inechanism, regardless of whether they can defend the arrangements displacing competition in a particular situation on grounds of convenience or efficiency. ${ }^{221}$

As one must draw a line between the per se rule and the rule of reason somewhere, the inost reasonable distinction seems to be one that makes all bidding agreements among actual bidders per se illegal, and subjects agreements ainong potential bidders, or between actual bidders and potential bidders, to the rule of reason. This approach would be far inore administrable, and more consistent with the approach followed in other contexts, than one that draws the rule of reason/per se distinction between bidding agreements that accompany asset divisions and those that do not or one that eliminates the per se rule entirely. Under this analysis, the bidding agreements in the battles for control that were described above-the agreements in the contests for J.P. Stevens, Federated Department Stores, Fruehauf, and American Standard-would all be per se illegal.

219. I discuss the concept of market power in the market for control at infra note 231 and accompanying text.

220. Thus agreements between bidders and non-bidders would be subject to the rule of reason even if made during the course of the auction.

221. See, e.g., Arizona v. Maricopa County Medical Soc'y, 457 U.S. 332, 351-54 (1982); United States v. Socony-Vacuum Oil Co., 310 U.S. 150, 220 (1940). 


\section{Limiting Principles Within the Rule of Reason}

Where the per se rule does not apply, the more general rule of reason governs. Relying on several limiting principles drawn from the antitrust analysis of joint ventures, one can distinguish those bidding agreements that may affect competition, and thus require further inquiry, from those that do not, and thus should be found per se legal.

\section{a. Substance Over Form}

Invocation of the joint venture label should not entitle otherwise per se illegal behavior to a rule of reason analysis. ${ }^{222}$ Because any collective action can, linguistically, be characterized as a joint venture, treating joint ventures more permissively than formal or informal cartels creates an obvious incentive to characterize cartels as joint ventures. For example, the defendant pipe manufacturers in United States v. Addyston Pipe \& Steel $\mathrm{Co}^{223}$ formed an "association ... for the purpose of avoiding the great losses they would otherwise sustain due to ruinous competition between defendants." 224 Care must be taken, therefore, to prevent more permissive standards for joint ventures from eroding the per se rule's clear proscription of naked restraints of trade. ${ }^{225}$ As a result, the courts have made clear since the beginning that characterizing naked restraints of trade as joint ventures would not affect the standard of review. ${ }^{226}$

\section{b. The First Principle: Actual or Potential Competitors}

Unless two or more of the participants in the venture are competitors or potential competitors, the combination should be per se legal. ${ }^{227}$ Thus unless $A$ and $B$ are both competitors or potential competitors for $T$,

222. Timken Roller Bearing Co. v. United States, 341 U.S. 593, 597-98 (1951) ("Nor do we find any support in reason or authority for the proposition that agreements between legally separate persons and companies to suppress competition among themselves and others can be justified by labeling the project a 'joint venture.' Perhaps every agreement and combination to restrain trade could be so labeled."), partially overruled on other grounds, Copperweld Corp. v. Independence Tube Corp., 467 U.S. 752 (1984); Engine Specialties, Inc. v. Bombardier, 605 F.2d 1, 11 (1st Cir. 1979) ("[J]oint ventures which partake of behavior identified as inherently pernicious . . . will be judged under the per se rule rather than the rule of reason. The talisman of 'joint venture' cannot save an agreement otherwise inherently evil.") (citing United States v. Sealy, 388 U.S. 350, 353 (1967)), cert. denied, 446 U.S. 983 (1980); see also Arizona v. Maricopa County Medical Soc'y, 457 U.S. 332 (1982); Brodley, Joint Ventures, supra note 185, at 1535-36.

223. 85 F. 271 (6th Cir. 1898), modified, 175 U.S. 211 (1899).

224. Id. at 273.

225. See White Motor Co. v. United States, 372 U.S. 253, 263 (1963), cited and quoted in Broadcast Music, Inc. v. Columbia Broadcast Sys., 441 U.S. 1, 20 (1979).

226. See, e.g., Citizen's Publishing Co. v. United States, 394 U.S. 131, $135-36$ (1969); Tïmken Roller Bearing, 341 U.S. at 598; Virginia Excelsior Mills, Inc. v. FTC, 256 F.2d 538, 540 (4th Cir. 1958); Addyston Pipe \& Steel, 85 F. at 291.

227. See 7 P. AREEDA, ANTITRUST LAw \ 1476, at 338 (1986); Brodley, Joint Ventures, supra note 185, at 1552-53; Pitofsky, Joint Ventures, supra note 185, at 1608-10; see also Pitofsky, Penn- 
the formation of $A B$ Acquisition is unlikely to pose any significant anticompetitive dangers. On' the contrary, $A B$ 's effects can only be neutral or positive. If neither had been able to enter the bidding independently, the formation of the group may introduce a new competitor into the market for corporate control; or, if one of the members of the group is already a competitor, the formation of the group may facilitate bidding for larger targets. ${ }^{228}$

This limiting primciple, by itself, implies that the vast majority of biddimg groups are per se legal. For example, no antitrust problems arise when Kohlberg, Kravis \& Roberts, a constant player in the market for corporate control, forms an investment partnership with a group of imstitutional imvestors and receives financial backing from a syndicate of commercial banks. Neither the imstitutional investors nor the commercial banks are competitors or potential competitors for control of target $T .229$

\section{c. The Second Principle: Power Over Price}

If the formation of the group does not create any power to reduce the price paid for $T$, then the group should be deemed per se legal. ${ }^{230}$ This is the "no market power" principle. ${ }^{231}$ Under this principle, if the

Olin, supra note 185 , at 1049-59. But see id. at 1059-62 (where one party is in market or would have entered anyway, joint venture should be per se illegal).

This principle must be subject to the commitment of form over substance. Thus, the rule of per se legality would not apply where a bidder and a non-bidder enter into a naked agreement eliminating the bidder from competition, such as greenmail. See infra text accompanying notes 26778. In such circumstances, because there is a bidding agreement, the concert of action requirement under section 1 is met. 6 P. AREEDA, ANTITRUST LAw If 1402, at 12, 15 (1986). And, because the effect of such an agreement is to ehminate a bidder, there is a clear threat to competition.

228. See, eg., United States v. FCC (Satellite Business Sys.), 652 F.2d 72, 96-102 (D.C. Cir. 1980).

229. By contrast, for purposes of mandating disclosure, some courts have held that a financier's involvement in the transaction approaches that of a bidder. See, eg., MAI Basic Four, Inc. v. Prime Computer, Inc., 871 F.2d 212, 221 (1st Cir. 1989) (Drexel Burnham characterized as a bidder and ordered to comply with SEC disclosure rules); Koppers Co. v. American Express Co., 689 F. Supp. 1371, 1388-91 (W.D. Pa. 1988) (holding Shearson's involvement in a hostile tender offer equivalent to that of a bidder). Even where not found to be a "bidder," courts have been willing to scrutinize the financier's involvement. See Polaroid Corp. v. Disney, 698 F. Supp. 1169, 1177-79 (D. Del.) (financial advisors in a tender offer not deemed bidders), aff'd in part, vacated in part, $862 \mathrm{~F} .2 \mathrm{~d} 987$ (3d Cir. 1988); City Capital Assocs. Ltd. Partnership v. Interco, Inc., 696 F. Supp. 1551, 1558 (D. Del. 1988) (concluding that Drexel Burnham was not a bidder, but warning that it came “dangerously close"), aff'd, 860 F.2d 60 (3d Cir. 1988).

230. Brodley, Joint Ventures, supra note 185, at 1541-43; Easterbrook, supra note 190, at 19-23; Pitofsky, Joint Ventures, supra note 185, at 1607-08; Williamson, Delimiting Antitrust, 76 GEO. L.J. 271, 281 (1987). See generally 7 P. AREEDA, supra note 227, at ๆ 1478.

231. This principle, as a general limiting principle in antitrust, is the subject of some controversy. Compare Easterbrook, supra note 190 (arguing that practices by firms that lack market power should be per se legal) with Markovitz, The Limits of Simplifying Antitrust, 63 TEX. L. REV. 41 (1984) (criticizing the market power filter as too difficult to administer, and arguing that even "powerless" firms can injure competition by merging or by driving out rivals). Most of the controversy, however, revolves around the principle's application to vertical restraints. In light of 
formation of $A B$ Acquisition does not enable $A$ and $B$ to reduce the price at which they can acquire $T$ or otherwise distort the contest for control of $T$, then it has no anticompetitive effects. ${ }^{232}$ If, for example, $A B A c q u i$ sition tries to cap the price paid for $T$ below its competitive level, it will simply lose $T$ to another bidder. ${ }^{233}$

\section{The Hard Cases}

After filtering the possibilities through the limiting principlesthereby eliminating agreements which are per se legal and per se illegalthe hard cases remain. As discussed above, if $A$ and $B$ are both actual competitors for control, that is, if each has already independently bid for control of $T$, the losses to competition of a joint venture between $A$ and $B$ in pursuit of $T$ are clearest, while the potential competitive benefits are most speculative. ${ }^{234}$ A net loss of one competitor occurs in a market where, by hypothesis, such a loss can affect the price paid. Accordingly, naked agreements between bidders should be per se illegal. ${ }^{235}$ Similarly,

the controversy, and in light of the difficulties in determining market power, this limiting principle must be applied gingerly in the context of the market for corporate control. See infra text accompanying notes 254-62.

Moreover, this principle's appropriateness depends in part on the commitment to substance over form outlined above. See supra text accompanying notes 222-26. The cases make clear that, as a matter of law, where there is a naked restriction of price or output, market power need not be proved. FTC v. Indiana Fed'n of Dentists, 476 U.S. 447, 460 (1986); NCAA v. Board of Regents, 468 U.S. 85, $109-10$ (1984); United States v. McKesson \& Robbins, Inc., 351 U.S. 305, 309-10 (1956); United States v. Socony-Vacuum Oil Co., 310 U.S. 150, 221 (1940); see also Klor's, Inc. v. Broadway-Hale Stores, Inc., 359 U.S. 207, 213 (1959) (holding that restraints affecting "powerless" firms are equally subject to the antitrust laws).

232. Moreover, there is also the potential procompetitive effect of the introduction of a new or more powerful bidder into the competition. Note that if $A$ independently has some power to cap the price paid for $T$-for example, it is clearly the highest valuing user-but the formation of $A B$ Acquisition does not increase that power, then the formation of $A B$ would be legal. This principle reflects the fundamental distinction under the antitrust laws between unilateral and concerted action. See, e.g., Copperweld Corp. v. Independence Tube Corp., 467 U.S. 752, 767-77 (1984).

233. As I discuss below, it may be very difficult, given the thinness of the market for eontrol, to determine whether or not $A$ and $B$ have any market power as to $T$. Moreover, it may be impossible to speak of a single "competitive price" in a thin inarket. Suppose, for example, that $A$ and $B$ are but 2 bidders out of 30 for control of $T$. One might say that under such circunstances, the formation of $A B A$ cquisition cannot cap the price paid for $T$. But that is not necessarily the case. If $A$ and $B$ are the two highest valuing users of $T$, then an agreeinent between $A$ and $B$ will, in fact, cap the price paid for $T$ at an amount marginally above the value of $T$ to the third-highest valuing user. By contrast, if $A$ and $B$ bid against each other, the winning bid will be inarginally higher than the value placed on $T$ by the second-highest valuing user.

234. See C. KAysen \& D. TuRneR, Antitrust Policy 136-41 (1959); Brodley, Joint Ventures, supra note 185, at 1552-53; Pitofsky, Joint Ventures, supra note 185, at 1608-09; see also Pitofsky, Penn-Olin, supra note 185, at 1042-45 (arguing for a per se prohibition in such a situation).

235. In a number of the bidding agreements described above, the target company was a party to the agreement dividing its assets. This occurred in the battles for J.P. Stevens as well as in the battle for Federated Department Stores. See supra notes 4 \& 5 .

Does the target board's acquiescence in such an agreeinent, or even an explicit waiver of its right to pursue antitrust claims, extinguish the antitrust claim arising out of the bidding agreement? 
if $A$ and $B$ are not both competitors or potential competitors for control, the effect of an agreement, absent other factors, is likely to be either neutral or procompetitive. Accordingly, such agreements should be per se legal.

But where $A$ is an actual bidder and $B$ is a potential bidder, or $A$ and $B$ are both potential (but not actual) bidders for control of $T$, the procompetitive and anticompetitive effects are less clear. ${ }^{236}$ Suppose, for example, that Campeau had teamed up with Macy's before either firm had bid for Federated, or after Campeau had bid but before Macy's had entered the contest. In such a situation, the gain to competition is speculative: a bidder where there might not have been one, or a better financed or more effective bidder in place of a weaker one. ${ }^{237}$ The loss to competition is likewise speculative: the possibility that Campeau and Macy's might have both bid for Federated imdependently. ${ }^{238}$

This is the true and unavoidable domain of the rule of reason. In these cases, there seems to be, or at least to have once been, a presumption that price or territorial restramts among jomt venturers are improper, ${ }^{239}$ and that any restraimts ancillary to a joint venture "1nust be limited to those inevitably arising out of dealings between the partners, or necessary (and of no broader scope than necessary) to make the jomt venture work."240 Recent cases suggest, however, that courts may be moving away from applying such a presumption. ${ }^{241}$

Probably not. First, the target board does not have the power to grant the bidders immunity from the antitrust laws. Second, the antitrust claim, if one exists, is not the target company's to waive: It is a direct claim of the shareholders because the shareholders, not the company, have suffered the mjury from the agreement capping the price for the company. See Cowin v. Bresler, 741 F.2d 410 (D.C. Cir. 1984); Eisenberg v. Flying Tiger Line, 451 F.2d 267 (2d Cir. 1971); Knapp v. Bankers Sec. Corp., 230 F.2d 717 (3d Cir. 1956); 12B W. Fletcher, Cyclopedia of THE LAw of Private Corporations $\S 5911$ (rev. perm. ed. 1980); 3B J. Moore, W. Taggart \& J. Wicker, MoORE's Federal Practice \{ 23.1.16[1], at 23.1-50 to -51 (2d ed. 1987).

236. This scenario describes the situation before the battle for control commences. Until that point, there are no actual bidders. Even a firm with a settled intention to bid is still a potential bidder at that stage as "there's many a slip 'twixt cup and lip."

237. See Brodley, Joint Ventures, supra note 185, at 1573-75.

238. See Pitofsky, Penn-Olin, supra note 185, at 1019-30.

239. See United States v. Topco Assocs., Inc., 405 U.S. 596 (1972) (horizontal territorial limitations constitute per se violations of the Sherman Act, notwithstanding partial integration among participants and likely efficiency gains); Timken Roller Bearing Co. v. United States, 341 U.S. 593 (1951) (agreements allocating tradc territories or fixing prices suppress competition, and a joint venture structure will not excuse otherwise unlawful conduct), partially overruled on other grounds, Copperweld Corp. v. Independence Tube Corp., 467 U.S. 752 (1984); Engine Specialties, Inc. v. Bombardier, 605 F.2d 1, 11 (1st Cir. 1979) (antitrust damages held to flow from "unfair and anticompetitive" behavior stemming from territorial allocations of markets), cert. denied, 446 U.S. 983 (1980); Virginia Excelsior Mills, Inc. v. FTC, 256 F.2d 538 (4th Cir. 1958) (price fixing through use of a common sales agent is per se illegal).

240. In re Brunswick Corp., 94 F.T.C. 1174, 1275 (1979), modified and aff'd sub nom. Yamaha Motor Co. v. FTC, 657 F.2d 971 (8th Cir. 1981), cert. denied, 456 U.S. 915 (1982).

241. Northwest Wholesale Stationers, Inc. v. Pacific Stationery \& Printing Co., 472 U.S. 284, 
There also seems to be a presumption that the likelihood that a joint venture will produce substantial procompetitive effects varies directly with the degree of integration among the joint venturers. ${ }^{242}$ Thus, to the extent that a joint arrangement lacks any significant integration and is hittle more than a joint bargainmg agreement, courts will presume it to be illegal. ${ }^{243}$ This presumption is im line with the general commitment to substance over form.

Leaving aside the question whether and what sort of presumptions there might be, ${ }^{244}$ the resolution of this class of cases undeniably poses difficulties and must inevitably depend on the circumstances of each particular case. ${ }^{245}$ Relevant mquiries would include: Does the formation of $A B$ create an additional bidder? Would $A$ and $B$, either independently or with other partners, have bid for $T$ in the absence of the joint venture? How many other bidders or potential bidders are there? Are there any factors mhibiting potential bidders from entering the auction? Does the formation of $A B$ create any efficiencies? How significant is the integration of assets and functions between $A$ and $B$ ? Finally, are the ancillary restraints adopted by the joint venture reasonably necessary for the achieveinent of its legitimate purposes? ${ }^{246}$ Inevitably, the answers to

$295-98$ (1985) (per se rule does not apply to joint ventures where there is real integration and substantial efficiencies are hikely); Rothery Storage \& Van Co. v. Atlas Van Lines, 792 F.2d 210, 229 (D.C. Cir. 1986) (same), cert. denied, 479 U.S. 1033 (1987); see also NCAA v. Board of Regents, 468 U.S. 85, 98-104 (1984) (per se rule does not apply to horizontal price fixing agreements in industries where such restraints are essential if the product is to be marketed at all); Broadcast Music, Inc. $v$. Columbia Broadcasting Sys., 441 U.S. 1, 23 (1979) (possibly the same). But see Arizona v. Maricopa County Medical Soc'y, 457 U.S. 332 (1982) (a joint bargaining agreement among hundreds of doctors resembles a horizontal price fixing agreement rather than a partnership and thus constitutes a per se violation of the Sherman Act).

242. Pitofsky, Joint Ventures, supra note 185, at 1614-24; see also Northwest Wholesale Stationers, 472 U.S. at 294-96; Broadcast Music, 441 U.S. at 19-21.

243. NCAA, 468 U.S. at 113-15 (1983); Maricopa County, 457 U.S. at 355-57; Brodley, Joint Ventures, supra note 185, at 1569-70; Pitofsky, Joint Ventures, supra note 185, at 1615-17; see also United States v. Socony-Vacuum Oil Co., 310 U.S. 150 (1940) (a joint buying program that creates no efficiencies does not constitute a partnership and is therefore a per se illegal restraint on trade).

244. See generally Brodley, Joint Ventures, supra note 185.

245. Compare Broadcast Music, Inc. v. Columbia Broadcasting Sys., 441 U.S. 1 (1979) (holding that blanket licensing of copyrighted music is not per se illegal, and remanding rule of reason inquiry to lower court) and NCAA v. Board of Regents, 468 U.S. 85 (1984) (where per se rule would otherwise be appropriate, not applied where availability of the product dependent on the restraints imposed) with Arizona v. Maricopa County Medical Soc'y, 457 U.S. 332 (1982) (negotiated maximum-fce agreements among doctors per se illegal).

246. In this context, the form of organization adopted by $A B$ Acquisition may make some difference. For example, if $A B$ Acquisition is an independent corporation, with separate management and shareholders, one is more likely to view it as an autonomous competitor than as a legal device designed to enable $A$ and $B$ to acquire $T$ jointly.

On the range of potentially relevant factors, sce United States v. Penn-Olin Chem. Co., 378 U.S. 158, 177 (1964); Berkey Photo, Inc. v. Eastman Kodak Co., 603 F.2d 263, 302 (2d Cir. 1979) ("The relevant variables might include: the size of the joint venturers; their share of their respective markets; the contributions of each party to the venture and the benefits derived; the likelihood that, 
these questions will depend on the nature of the competition for control of $T$. Here, at least, the difficulties of applying the rule of reason cannot be avoided.

\section{Subsidiary Questions}

\section{Who Is a Bidder?}

The above analysis requires that one identify and distinguish among actual bidders, potential bidders, and nonbidders. A firm that has already bid for control of $T$ is clearly an actual bidder, but it is easy to imagine more difficult cases. Suppose, for example, that $A$ has issued a press release announcing an intention to bid for Target $T$, but has not yet made a tender offer. Or, suppose that $A$ has proposed a friendly merger to $T$ 's board. And finally, suppose that $A$ has submitted a bid for $T$, conditional upon board approval or conditional on financing. In which of these situations is $A$ a bidder for $T$ ? Is $A$ 's investment banker who takes an equity or quasi-equity position in a takeover also a bidder? ${ }^{247}$ These are factual questions that must be considered in identifying bidders. ${ }^{248}$

The identification of potential as opposed to actual bidders raises even more difficult problems. Two overlapping types of potential bidders are relevant to the antitrust analysis: "actual" potential competitors and "perceived" potential competitors. ${ }^{249}$ An actual potential competitor is a firm or individual who is likely to enter the market. ${ }^{250}$ If $C$ is likely to enter the contest for $T$, then a bidding agreement or jomt venture

in the absence of the joint effort, one or both parties would undertake a similar project, either alone or with a smaller firm in the other market; the nature of the ancillary restraints imposed and the reasonableness of their relationship to the purposes of the venture."), cert. denied, 444 U.S. 1093 (1980).

247. The issue is related to, but not the same as, the question of who must comply with the SEC disclosure rules for tender offers. In light of the Williams Act's purpose of providing information to the shareholders of the target companies, the standards for determining who is a bidder for disclosure purposes will likely be different, and more expansive, than the standards for determining who is a bidder for antitrust purposes. On the question of who is a bidder for disclosure purposes, see, for example, cases cited supra note 229.

248. Identification issues, however, do not generally arise in cases involving bidding agreements. This seems to be for two reasons. First, in a typical case, say bidding agreements among bidders at a used machinery auction, it is clear from independent evidence that the parties to the agreement are competitors: They are all, for example, dealers in used machinery. In the market for corporate control, only a relatively few firms are independently identifiable as dealers in used corporations. Second, the typical case involves a fairly explicit bidding agreement that may itself be sufficient to establish that the parties to it are competitors.

249. See United States v. Marine Bancorp., 418 U.S. 602, 623-25 (1974) (elimination of actual or perceived potential competitors may render a merger unlawful); United States v. Falstaff Brewing Corp., 410 U.S. 526, 531-37 (1973) (focus of the potential competition doctrine is on the likely effects of the potential competitor's premerger position on the fringe of the target market); Penn-Olin, 378 U.S. at $172-74$ (both actual and perceived potential bidders may have a procompetitive effect).

250. Marine Bancorp., 418 U.S. at 623-25; Falstaff Brewing, 410 U.S. at 531-37 (Marshall, J., 
between $C$ and $A$ will eliminate $C$ as a competitive force. A "perceived" potential competitor is a firm or individual that firms currently in the market view as a likely market entrant. ${ }^{251}$ The very existence of a perceived potential competitor may have a procompetitive effect on a concentrated market. In other words, if $A$ and $B$ view $C$ as a likely entrant, whether or not $C$ is in fact planning on entering the bidding, $C$ 's independent presence may exert a procompetitive effect on the market by forcing $A$ and $B$ to bid higher to avoid tempting $C$ into the auction. While the question whether $C$ is an actual potential competitor focuses on what $C$ might do, the question whether $C$ is a perceived potential competitor focuses on how $C$ is viewed by those in the market. ${ }^{252}$

\section{Market Power}

The most difficult and central issue raised by the above limiting principles involves identifying the circumstances in which bidders have power in the market for corporate control. Under an expansive view of the market for corporate control, very few if any bidders will have any market power at all. For example, if defined as a single national market, the market for control might seem to be extremely unconcentrated, ${ }^{253}$ with no significant barriers to entry (all you need is money) and, therefore, none of the players (bidders or potential bidders) would seem to have any market power. Under this view, my analysis would come close to collapsing because, according to my second principle, all bidding groups would be legal.

Not surprisingly, I disagree with this view. Whether, and the extent to which, $A$ and $B$ have market power depends on who is likely to bid for $T$ in particular, rather than who occasionally bids in the general market for corporate control. The market definition analysis also must reflect the realities of the market for corporate control: the thin nature of the market for control, the severe time constraints governing control contests, and the collective choice problems that can limit or eliminate the

concurring). The Supreme Court has twice reserved, and never ruled, on the viability of the actual potential competition doctrine.

251. See Marine Bancorp., 418 U.S. at 623-25; Falstaff Brewing, 410 U.S. at 531-37.

252. In order to establish the perceived potential competition or "waiting in the wings" effect, one must prove that the market in which the joint venture would operate was not competitive in structure, that the competitors in the market would have perceived the nonentering party as a likely potential entrant, that the nonentering party was one of the few most likely potential entrants (so that the loss of the potential competition would be a significant loss), and, finally, that the wings entrant would have a substantial and likely procompetitive effect on the market. See United States v. Marine Bancorp., 418 U.S. 602 (1974); Pitofsky, Joint Ventures, supra note 185, at 1609-10. In the thin market for corporate control, the perceived potential competition argument would be limited to battles for control among a small number of bidders, where the potential competitor would be one of the two or three most likely new entrants into the contest.

253. Examination of the transactions in the market for control over last year might disclose that no single player had more than perhaps a $2 \%$ share of the total market. 
target's ability to refuse an offer and to extend an auction. ${ }^{254}$

To illustrate, consider the following hypothetical: $A$ and $B$, two large pubhicly held printing companies, bid jointly for $T$, another large publicly held printing company. Suppose further that a very large nuinber of sinall local printing coinpanies and ten large publicly held printers inake up the printing industry. Only the large printers have the capacity and the ability to bid for the large projects, such as printing T.V. Guide or the Yellow Pages. Furthermore, the printing industry is fairly complex and a firm's expertise in operations and narketing determine, in large ineasure, how well it performs. Finally, over the last ten years, all of the acquisitions of large printers have been either by other large printing companies or by means of inanagement leveraged buyouts.

Do $A$ and $B$ have the power to limit the price paid for $T$ ? Consider how an investment banker might go about inarketing $T$ if given the assignment. ${ }^{255}$ The banker would concentrate on the ten large firms and might also approach the leveraged buyout firns that lad been involved in the management buyouts. To gauge whether there was interest by firns outside the industry, the banker would issue press releases indicating that the coinpany was for sale. Finally, if there were some large foreign firms interested in entering the U.S. printing market by acquisition, the banker would approacli thein. All in all, there would be a pool of potential acquirers of perhaps fifteen to twenty firms.

The field would then be narrowed. Some of the potential acquirers would turn down $T$ for a variety of reasons: Soine iniglit have made a recent acquisition and not be in a position to bid for another firn; some might not be interested in unerging with $T$ because of $T$ 's union plants; soine might feel that $T$ would not be a "good fit" with their present business and goals; and finally, some simply inight not like $T$ or be able to afford it. Of the original pool of fifteen to twenty bidders, the investment banker might, at best, be able to solicit two serious bids. ${ }^{256}$ Under such

254. FTC v. Indiana Fed'n of Dentists, 476 U.S. 447, 460-61 (1986) (citing and quoting 7 P. AREEDA, supra note 227, ๆ 1511, at 429); NCAA v. Board of Regents, 468 U.S. 85, 109-10 (1984).

255. For an example of how investment bankers actually market companies, see Solash v. Telex Corp., [1987-1988 Transfer Binder] Fed. Sec. L. Rep. (CCH) I 93,608, at 97,724-25 (Del. Ch. Jan. 19, 1988).

256. See, e.g., Cottle v. Storer Communication, Inc., 849 F.2d 510 (11th Cir. 1988) (Storer's directors, a majority of whom were committed to selling the company, searched from March through July for potential bidders, but found only two who indicated any interest); Hanson Trust PLC v. ML SCM Acquisition, Inc., 781 F.2d 264, 269 (2d Cir. 1986) ("[N]one of over forty companies contacted [by Goldman Sachs] were willing to act as a 'white knight,' and that of three LBO firms contacted, ... only Merrill [Lynch] was interested in participating in a leveraged buyout."); Solash, [1987-1988 Transfer Binder] Fed. Sec. L. Rep. at 97,723 ("[The Memorex] prospect was developed after a canvass of some fifty firms failed to uncover any active interest in acquiring the company at prices reflecting a comparable premium to that being offered by Memorex."); Thompson v. Enstar Corp., 509 A.2d 578, 581 (Del. Ch. 1984) ("[A]fter contact with 
circumstances, those two bidders would indeed have significant power to affect the price paid for $T$.

This hypothetical chain of events illustrates the bidder's power in a thin market. It also provides a plausible scenario for the sale of many companies simce the market for control of companies is typically a thin market. ${ }^{257}$ The thinness of the market in many circumstances-the relative paucity of buyers and sellers for any particular type of companygives many bidders significant potential niarket power.

Moreover, the accelerated pace of contests for corporate control may discourage additional bids. There is a direct relationship between the aniount of time the investment banker has to market the firm, or the duration of the battle for control, and the nuniber of firms that will bid for the target. ${ }^{258}$ Some firms that night otherwise be interested may simply be unable to put together a bid in a matter of days or weeks. Finally, the dispersed shareholders of a publicly held target conipany do not have the sanie ability as a sole owner does to extend an auction, seek out or wait for additional bidders, or not sell. ${ }^{259}$ Thus the "distorted choice" facing target shareholders, like the accelerated pace, may reduce the number of competing bids. ${ }^{260}$

Consider, by contrast, the sale of an easily valued and liquidated firm such as an (undervalued) closed-end nuutual fund. ${ }^{261}$ There one would expect a relatively large nuniber of bidders whose valuations for the firm would be close to identical (that is, the net asset value minus acquisition and liquidation costs). A joint bidding venture between two

over 100 prospects, and after an indepth review by 26 seriously interested buyers, only one firm offer was before the board ....").

257. See supra notes 31-37 and accompanying text.

258. Macey \& McChesney, A Theoretical Analysis of Corporate Greenmail, 95 YALE L.J. 13, 23 (1985).

259. See supra notes $115-35$ and accompanying text.

260. My argument here is not that $A$ and $B$ are monopolizing the market for the shares of $T$. Rather, companies are unique in a way that shares of a given company are not. As discussed above, it may be that as to a given company at a given time, there will be very few potential bidders. See supra text accompanying note 35 . If so, those bidders have some market power, that is, the power to limit the price paid for that company.

The situation is different as to the shares of a given company. For example, in the printing industry illustration discussed above, even if one is unwilling to eonclude that the shares of $T$ constitute a relevant inarket, one must concede that bidders $A$ and $B$ might have some market power as to control of Target $T$. There are many more investors willing to purchase shares in $T$ for investment purposes than there are firms willing to bid for control of $T$. Moreover, there are far more competing products in the market for shares than the market for control. An investor looking to invest in a stock is, according to classical capital asset pricing theory, looking for a particular combination of expccted return and systematic risk. See, e.g., Gilson \& Kraakman, Mechanisms of Market Efficiency, 70 VA. L. REv. 549, 630 (1984). For any given security, including shares of $T$, there are a vast number of substitutes. Id. By contrast, there are very few alternatives to $T$ for a printing company looking to acquire another printing company.

261. See, e.g., Clemente Global Growth Fund, Inc. v. Pickens, 705 F. Supp. 958 (S.D.N.Y. 1989). 
potential bidders for such a firm would be far less likely to pose any competitive threats.

As a result, given that the market power inquiry serves as a surrogate for a showing of actual detrimental effects on competition, ${ }^{262}$ the appropriate analysis must be sensitive to the market dynamics of a particular contest for control. Any determination of market power must be based on the reahities of buying and selling particular companies rather than on a generalized view of the market for corporate control as a whole.

\section{E. Greenmail Through the Antitrust Lens}

The general analysis sketched out above is directly apphicable to the issue of negotiated stock repurchases, or "greenmail." Greenmail is the practice whereby a corporation buys back a minority block of stock at an above market price to forestall a threatened hostile tender offer. ${ }^{263}$

The Delaware courts apply a two-step analysis to challenged greenmail payments. They first examine the purpose behind the greenmail and disallow any greenmail payments that were primarily or solely intended to entrench management. ${ }^{264}$ They then ask whether the payment was reasonable in relation to the threat posed to shareholder or corporate interests. ${ }^{265}$ Under this approach, because the greenmailer does not ordinarily owe any fiduciary duties to the shareholders, demanding or accepting greenmail does not violate Delaware law. ${ }^{266}$

From the antitrust perspective, what is perhaps most striking about greenmail is not the possibility it raises of management entrenchment per se, but that it is an explicit and naked agreement not to bid. On its

262. NCAA v. Board of Regents, 468 U.S. 85, 109-10 (1984).

263. Unocal Corp. v. Mesa Petroleum Co., 493 A.2d 946, 956 n.13 (Del. 1985).

264. Polk v. Good, 507 A.2d 531, 536-37 (Del. 1986); Unocal, 493 A.2d at 953-55; Cheff v. Mathes, 41 Del. Ch. 494, 504, 508, 199 A.2d 548, 554, 556 (Del. 1964).

265. Polk, 507 A.2d at 536-37; Unocal, 493 A.2d at 953-55.

266. See Ivanhoe Partners v. Newmont Mining Corp., 535 A.2d 1334, 1344 (Del. 1987) (under Delaware law, a shareholder owes a fiduciary duty to other shareholders only if it also holds a majority interest in or exercises control over the business affairs of the corporation); Unocal, 493 A.2d at 958; Aronson v. Lewis, 473 A.2d 805, 815 (Del. 1984). If, however, the greenmailer becomes a fiduciary of the target shareholders-for example, by filing a derivative suit or a class action-he may no longer be able to accept greenmail. Heckmann v. Ahmanson, $168 \mathrm{Cal}$. App. 3d 119, 214 Cal. Rptr. 177 (Ct. App. 1985). For illustration, see the press account of the settlement over Saul Steinberg's greenmail of Disney in Wall St. J., July 13, 1989, at A2, col. 5. Moreover, some courts have held that a greenmailer may be liable as an aider and abetter of management's breach of fiduciary duty. Fry v. Trump, 681 F. Supp. 252 (D.N.J. 1988); Feinberg v. Carter, 652 F. Supp. 1066 (S.D.N.Y. 1987); Heckmann v. Ahmanson, 168 Cal. App. 3d 119, 214 Cal. Rptr. 177 (Ct. App. 1985). While the Delaware courts have not found greenmailers liable under Delaware corporate law, their opinions manifest an undisguised hostility to the practice and practitioners. See, e.g., Ivanhoe Partners, 535 A.2d at 1342, 1345-46. 
face, greenmail seems to undermine the normal competitive process. ${ }^{267}$ Consider again the classic bidding agreement in which $A$ pays $B$ not to bid for Target $T$. Greenmail fits this pattern perfectly: Management pays actual or potential bidder $G$ not to bid for the company. In terms of the framework, $A$ is either $T$ or $T$ 's management, depending on whether $T$ 's management is acting on behalf of $T$ 's shareholders or on its own behalf. $G$ is the "greenmailer." The typical agreement is that $A$ repurchases $G$ 's shares at an above-market price, and $G$ agrees not to bid for $T$ without the approval of $T$ 's board.

As in the corporate law analysis, $T$ 's management is likely to be acting either on behalf of the shareholders or on its own behalf. Within the second category, three situations may be distinguished: T's managers may simply be seeking to preserve their corporate positions (the entrenchment case); $T$ 's managers themselves may be a bidder for control of $T$ (the actual bidder case); and finally, $T$ 's managers, while not bidding for control of $T$, would do so to forestall a hostile takeover (the potential bidder case). ${ }^{268}$

The general antitrust analysis set forth above suggests that where $T$ 's management is an actual bidder, greenmail is no more than a naked bidding agreement between competing bidders and should be deemed per se illegal. Where $T$ 's management is not an actual bidder, the rule of reason should apply. Under the rule of reason, however, unless the greenmail payment can be shown to have been, on balance, procompetitive, it should be illegal.

Consider, first, the actual bidder situation. Suppose that $T$ 's management is engaged in a buyout of $T$ when it causes $T$ to repurchase $G$ 's shares for a premium. This situation presents both the severest breach of the duty of loyalty, as well as the most serious antitrust problems. From an antitrust perspective, management as a bidder enters into an agreement with a competing bidder and pays the competing bidder not to bid. $^{269}$ As discussed at length above, such agreements between actual bidders should be per se illegal because their anticompetitive effects are clear, while their procompetitive effects are speculative or nonexistent. ${ }^{270}$ Note that in this situation, the agreement between $T$ 's management and

267. Coffee, supra note 22, at 1290 ("[Greenmail] in effect short-circuits the control contest that should result; rather, there is a perverse auction in which the competing bidders are the target corporation (whose management plainly suffers from a conflict of interest) and any potential bidder (if indeed there is one) actually interested in acquiring control of the target.").

268. Reserve for now the question whether it is feasible to distinguish among these possibilities.

269. Using shareholders' money to buy off the competing bidder does not raise any additional antitrust problem.

270. See supra notes 192-221 and accompanying text. Somc of the bidding agreements discussed above entail agreements between actual bidders. See, e.g., supra note 6 (describing the battles for control of American Standard and Fruehauf). 
$G$, the greenmailer, results in neither a new bidder, nor even a more powerful bidder for control. As such, the anticompetitive effect is clear, while the procompetitive effect is nil. This is the same result that one would expect under Delaware law: Where management is a bidder, the board may not favor the management offer over a more attractive outside bid. ${ }^{271}$ A possible difference, however, is that under the antitrust approach, the greenmailer would clearly be liable to the shareholders.

Now consider the potential bidder situation. Suppose that $T$ 's managers are not currently planming or engaged in a bid for control of $T$, but would bid for $T$ if outside bidders could not be dissuaded from bidding (and presumably replacing current management if successful). This seems to be a common situation, especially when a significant amount of financing is available for management leveraged buyouts. ${ }^{272}$ Management sometimes bids only because it is unable to mamtain the status quo through the use of standard defensive measures.

In this situation, greenmail causes a net loss of two bidders, management and the greenmailer. Although that is not twice as bad as when management, an actual bidder, pays the greenmailer not to compete (because the possibility of a future auction for control remains), it nonetheless poses serious dangers to competition for control. Under the present analysis, the agreement is one between a bidder (the greenmailer) and a potential bidder ( $T$ 's management), and, as such, it would be subject to the rule of reason.

How would the rule of reason analysis proceed? The anticompetitive effects are fairly clear: One actual and one potential bidder are eliminated, at least temporarily. Are there any procompetitive effects in this situation? Some have argued that greenmail may be procompetitive. ${ }^{273}$ Others have countered that the number of situations in which greenmail might be procompetitive, especially when management is acting out of self interest, are exceedingly small, and that greenmail can be procompetitive only under heroic-and implausible-assumptions. ${ }^{274}$ Under an antitrust analysis, one would now confront the questions whether, as a practical matter, procompetitive greenmail can be distinguished from anticompetitive greenmail, and whether greenmail is procompetitive

271. See, e.g., Mills Acquisition Co. v. MacMillan, Inc., 559 A.2d 1261 (Del. 1989); Robert M. Bass Group, Inc. v. Evans, 552 A.2d 1227 (Del. Ch. 1988); City Capital Assocs. Ltd. Partnership v. Interco, Inc., 551 A.2d 787, 803 (Del. Ch. 1988).

272. Bradley, Desai \& Kim, supra note 15, at 32-39 (treating management as potential bidder).

273. See, e.g., Booth, State Takeover Statutes, 86 MICH. L. REV. 1635, 1662-63 (1988); Macey \& McChesney, supra note 258; Oesterle, The Negotiation Model of Tender Offer Defenses, 72 CORNELL L. REv. 117, 146 (1986); Schleifer \& Vishnay, Greenmail, White Knights, and Shareholder Welfare, 17 RAND J. ECON. 293 (1986).

274. Gordon \& Kornhauser, Takeover Defensive Tactics: A Comment on Two Models, 96 YALE L.J. 295, 31 1-19 (1986); see also Note, Greenmail: Targeted Stock Repurchases and the ManagementEntrenchinent Hypothesis, 98 HARV. L. REV. 1045 (1985). 
often enough to make a case-by-case analysis of greenmail's competitive effects worth the bother and costs (both of administration and reduced deterrence). Under a rule of reason inquiry, the defendants would have the burden of establishing the procompetitive character of the contested payment, a burden that, even accepting that greenmail could sometimes be procompetitive, would be hard to carry.

Consider, now, the entrenchment case, which raises both corporate governance and antitrust problems: $T$ 's managers are violating their duties to $T$ 's shareholders by agreeing with $G$ to stop competing in the market for control. The Delaware courts have stated that such entrenchment is a breach of fiduciary duties. ${ }^{275}$ Under the present analysis, because $G$ and $T$ 's management are not both competitors for control, a rule of reason analysis should apply, unless one concluded that the difficulties in distinguishing procompetitive from anticompetitive greenmail, and the unlikelihood of greenmail being procompetitive, would mandate a per se rule. As above, the anticompetitive effect is clear: A competitor for control has been elimmated. Furthermore, under a rule of reason approach, the defendants would again liave the difficult burden of establisling that paying greenmail for the purpose of entrenching incumbent management is procompetitive.

Finally, one can apply the same approach to the situation where management is attempting to furtlier shareholder interests. Under the Delaware approacl, if management is acting out of a good faith concern for shareholder welfare, greenmail is permissible so long as it is a reasonable response to the perceived danger. ${ }^{276}$ By contrast, under the antitrust analysis, sucli greenmail would be permissible only if its procompetitive effects outweighed its anticompetitive effects. Unless good faith greenmail were, as a general matter, procompetitive, the two approaches would yield different results.

The antitrust analysis applied to greenmail would tlius result in a per se rule wliere management is a bidder or potential bidder, and presumptively a rule of reason in all other cases. Within this general analysis, there is, of course, much room for argument. If one concluded with Professors Gordon and Kornhauser that the likelihood of greenmail being procompetitive is vanishingly small, ${ }^{277}$ one might opt for a blanket per se rule rather than incur the expense and uncertainty of a rule of reason analysis. Similarly, because of the difficulties of distinguishing procompetitive from anticompetitive greenmail, and the clear effect on competition, one might argue that a per se prohibition would be

275. See cases cited supra note 264.

276. See cases cited supra note 264.

277. See sources cited supra note 274. 
appropriate. $^{278}$

But this analysis, when apphied to good faith greenmail, seems to miss much of what is goimg on. What makes good faith greenmail difficult is not that management is trying to mcrease competition, but rather, that management is trymg to protect the shareholders from competition, specifically, competition among themselves. ${ }^{279}$ Consider a typical greenmail scenario: The greenmailer, $G$, acquires a $5 \%$ share of the target, $T$, a firm whose stock has been trading at about $\$ 50$ per share. $G$ makes a two-tier, bust-up, junk-bond bid of $\$ 60$ cash for the first $46 \%$ tendered, and $\$ 50 \mathrm{~m}$ notes for the remaining $49 \%$, for a blended value of around $\$ 55$ per share, depending on how the notes are valued. T's board concludes that the bid is madequate because $T$ 's mvestment bankers advise that the firm could be sold im a negotiated transaction for at least $\$ 70$ per share cash. Moreover, $T$ 's board concludes that the two-tier bid threatens shareholder imterests because it is coercive: Each shareholder, realizing that the other shareholders are likely to tender into the front end im order to secure at least a pro rata share of the cash consideration, will likewise feel compelled to tender, even if the shareholder behieves that $T$ is worth more than $\$ 55$ per share.

In these circumstances, the Delaware courts would probably uphold a good faith management decision to buy off $G$ with greenmail. ${ }^{280}$ But if the Delaware courts would permit such greenmail, it is not because of a behef that such greenmail somehow increases competition for control, but because such payments would be perceived to be in the shareholders'

278. Indeed, even in most situations where paying greenmail might, on balance, be procompetitive, alternatives exist that are less restrictive of competition. For example, consider the situation where management believes that a third party exists who would top the potential greennailer's bid if given time to enter the auction. Professors Macey and McChesney argue that in this situation it might be procompetitive to pay greenmail. See Macey \& McChesney, supra note 258. But that hardly seems to be the case. Not only does greenmail deprive the shareholders of the benefit of competition between the greenmailer and the third party-competition that may be essential to getting the price above what the greenmailer has offered, Gordon \& Komhauser, supra note 274, at 316-but there are cheaper and less restrictive alternatives. See Gordon, Ties that Bond: Dual Class Common Stock and the Problem of Shareholder Choice, 76 CALIF. L. REv. 3, 13-14 (1988). Under Delaware law, it is clear that target management may adopt a poison pill to gain time to solicit competing bids. See, e.g., City Capital Assocs. Ltd. Partnership v. Interco, Inc. S51 A.2d 787, 798 (Del. Ch. 1988).

279. See, e.g., Oesterle, supra note 273 , at 143 (Greenmail and poison pills "[b]oth consolidate shareholder bargaining power in the target board where necessary to respond effectively to a tender offer.").

280. There is, it seems to me, a very substantial basis for questioning such good faith greenmail in these circumstances, even under current Delaware law. Given the existence of cheaper and more effective defensive alternatives that address the perceived threat posed by a two-tier, front-end loaded offer, greenmail should no longer be considered a reasonable response to such a threat. Thus, under Unocal, greenmail should not be permitted even in these circumstances. Indeed, judicial approval of at least limited use of poison pills may both be a consequence of the judicial dislike of greenmail and greenmailers, see supra note 266 , as well as a cause of the decline in greenmail generally. I know of no cases in which this argument has been made. 
interests, irrespective of their effect on competition for control. That is one critical difference between the Delaware approach and a market-oriented approach. ${ }^{281}$

But does it make sense to prohibit greennail that may be in the shareholders' interest because it is, on balance, anticompetitive? This is a very hard question, a unuch harder question than whether bidding agreeinents among competing bidders should be prohibited. The basic issue is the question of how far competition should extend into the corporate sphere. In this classic greenmail situation, when management acts in good faith, it typically does not pay greenmail to gain time to solicit alternative bids, or even because shareholders as a group inight value the firm more highly than the bidder-arguably procompetitive goals-but to protect $T$ 's shareholders from the competition to tender from other shareholders. A two-tier bid becomes "coercive" as a result of two features of the corporate context: the competition among shareholders, and the ability of a majority shareholder either to freeze out the minority shareholders or, even worse for the minority, to operate the corporation in a inanner that disadvantages the minority. What stampedes shareholders is the realization that others will tender, and that non-tendering shareholders will be either consigned to the less valuable second stage or left holding illiquid and relatively unprotected shares.

Greenunail and a host of other defensive measures seek to control this competition between shareholders. Greenmail, poison pills, supermajority voting, and fair price charter amendments each try to limit the effect of the competition ainong shareholders to tender, thereby allowing management, bargaining on behalf of the shareholders, to maximize shareholder gains, either by soliciting competing bids, negotiating a transaction, or remaining mdependent.

If the majority could not freeze out or otherwise disadvantage minority shareholders, the question would be a good deal simpler. In that case, the situation would look very similar to any other competition among sellers. If, as a general matter, we do not protect sellers of screws, boxes, or legal services from competition from other sellers, even if the competition "coerces" them to sell at a price equal to marginal cost, it is hard to see why sellers of shares should be treated differently. The collective action dilemina that faces target shareholders (it is better for all if none tenders, but, absent enforceable coordination, it is better for each to tender) is identical to the dilemma facing any group of competing buyers or sellers (it is better for all if none sell screws below the monopoly price, but, absent enforceable coordination, it is better for each to do so). In large measure, the purpose of the Sherman Act is to prevent competitors

281. See supra note 276 and accompanying text. 
from escaping from that quasi-prisoners' dilemma. The problem is that shareholders, because they can be frozen out or, perhaps worse, left as minority shareholders in a firm controlled by the bidder, are in a materially different position. Because I do not yet know the extent to which competition among shareholders should be preserved (a question of competition in the intra-corporate sphere), as distinguished from competition between bidders (competition in the inter-corporate sphere), I cannot yet resolve the question whether the antitrust laws should prohibit good faith greenmail.

In the end, then, the antitrust analysis of greenmail may raise as many questions as it answers. Nonetheless, the virtues of an antitrust analysis of greenmail are twofold. First, it focuses on one of the basic problems with greenmail: its effect on competition in the market for control. Second, the antitrust approach, unlike the corporate law approach, provides a solid foundation for extending primary liability to those who deinand or accept greenmail. But on the most difficult question, how to evaluate greenmail paid in a good faith attempt to protect target shareholders, the antitrust analysis is not notably more successful than the Delaware corporate law analysis. Moreover, because the antitrust analysis is inconclusive on the question of good faith greenmail, it faces the same difficulty that causes the Delaware analysis to founder, namely, low to distinguish between good faith and bad faith greenmail, or between procoinpetitive and anticompetitive greenmail. The principle virtue of this aspect of the antitrust analysis is that it focuses attention on what, to me, is the fundamental question in the evaluation of defensive measures: to what extent should competition among sliareliolders to tender be preserved?

\section{CONCLUSION}

In this Article, I liave argued, first, that the market for corporate control, like other markets in the economy, requires the fundamental protections of the antitrust laws and, contrary to the only cases on point, sliould not be left unprotected. Second, I have sketclied out a general analysis of how the antitrust laws should be applied to the market for control. Specifically, I have argued that naked and nearly naked restraints of trade witlin that market, as exemplified by bidding agreements among competing bidders in battles for control, pose significant anticoinpetitive dangers without significant countervailing procompetitive virtues, and therefore should be per se illegal. Finally, I have applied this general approach to "greenmail."

Many questions remain unanswered: What are the boundaries of the per se rule prohibiting bidding agreements by competitors? How are the tough questions that arise under the rule of reason analysis resolved? 
What other elements of the antitrust laws should apply within the market for control, if any? Should the statutory scheme be reformed to vest regulation over competition within the market for control in the SEC alone?

As difficult as these questions may be, they must be faced and resolved. We cannot, and should not, ignore the protection of the basic competitive processes within the market for corporate control, nor should the issue be swept under the rug by means of the strained linguistic argnment that has been adopted by a number of courts. To say, as those courts have, that the antitrust laws do not apply because battles for control are not "trade or commerce" for the purpose of the Sherman Act is indefensible. Competition for control is too important to both antitrust and corporate law. 


\title{
California Law Review
}

\begin{tabular}{lll}
\hline \hline Vol. 77 & DECEMBER 1989 & No. 6
\end{tabular}

Copyright (C) 1989 by California Law Review, Inc.

\section{BOARD OF EDITORS}

\author{
1989-90
}

Editor-in-Chief

JOHN TINKHAM

Managing Editor

JOHN F. CHASE

Senior Articles Editor

STEVEN L. FriedLANDER

Articles Editors

JULIET BROWNE

LINDA FOY

Patricia L. Godsey

Michael Miller

ERIC M. BROOKS

DAVID B. FELDMAN

ERIC GRANT

STEVEN HARDY

JON HINCK.

David P. Hubbard

LIBBY JACOBS

Miranda Kane

NANCY KIM

ANNA MARIE ARMSTRONG

D. CAMERON BAKER

ADAM BATTANI

JAMES E. BAYLES, JR.

MARGUERITE BUI

EDWIN BURGOS

Paula Chertok

Laura M. Craska

MARIA LISA CRISERA

AUDRA ECKERLE

PaUl Edvards

Steven Ellis

GAIL ENGSTROM

ANN FOERSCHLER
Senior Executive Editor

JENNIFER UPHAM

Executive Editors

RICHARD E. LEAHY

HELEN SHIN

LAURine Tuleja

Research \& Topics Editor KIM THOMPSON

Associate Editors

Margaret LiN DAVID MCGOWAN

Clare Maier MICHAEL MORRISSEY SCotT G. Parker

MARIA RABASSA

ROBERT RENNER

STEVEN RINKLE

ROBIN ROGERS

\section{Members}

Bruce D. Gellman

Carl Goldberg

JOHN HARTENSTEIN

DEAN M. KATO

J. MONICA KIM

SCOTT KRONLAND

MARK LEMLEY

LUIS LI

JoHN MACPETE

ANDREW MASTIN

CAROLYN F. MCNIVEN

TIMOTHY A. MILLER

Christian Nadan

MARTIN NicholS

Office Manager

MARY P. NeLSON
Senior Note \& Comment Editor

RUSS ELMER

Note \& Comment Editors Christopher ConNer

MARETA C. HAMRE

NAOMI ROHT-ARRIAZA

Catherine Salton

TAMARA SEYLeR-JAMES

ROBERT SILTANEN

JOHN SITHER

MORGAN SMOCK

MARIA ISABEL TAN

Melissa Thomas

JANA WINOGRADE

Michael Page

Paul G. Prince

DON SCARAMASTRA

WENDY SCHMIDT

KATE SCHNEIDER

SeAn M. SeLegue

ANDREW SHAGRIN

KIMBERLY SMITH

SID SPAETH

Marta Tanenhaus

RAGESH K. TANGRI

JESSICA C. VAPNEK

TAY C. VIA

Natasha ZaLkIN 
· 